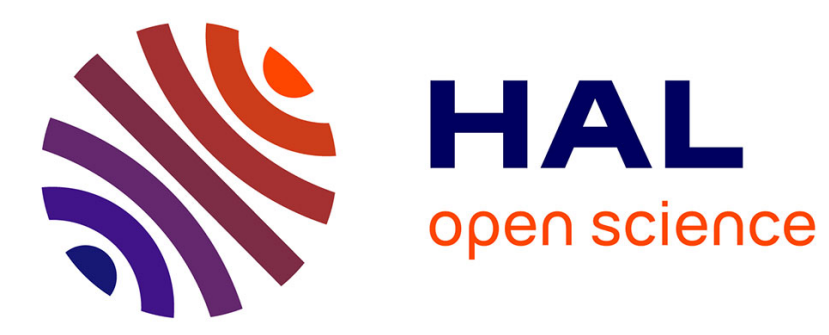

\title{
New insight of sedimentological and geochemical characterization of siliciclastic-carbonate deposits (Alveolina Limestone Formation, Graus-Tremp basin, Spain)
}

Youri Hamon, Rémi Deschamps, Philippe Joseph, Daniel Garcia, Emmanuelle

Chanvry

\section{To cite this version:}

Youri Hamon, Rémi Deschamps, Philippe Joseph, Daniel Garcia, Emmanuelle Chanvry. New insight of sedimentological and geochemical characterization of siliciclastic-carbonate deposits (Alveolina Limestone Formation, Graus-Tremp basin, Spain). Bulletin de la Société Géologique de France, 2016, 187 (3), pp.133-153. 10.2113/gssgfbull.187.3.133 . hal-01311499

\author{
HAL Id: hal-01311499 \\ https://hal.science/hal-01311499
}

Submitted on 12 May 2016

HAL is a multi-disciplinary open access archive for the deposit and dissemination of scientific research documents, whether they are published or not. The documents may come from teaching and research institutions in France or abroad, or from public or private research centers.
L'archive ouverte pluridisciplinaire HAL, est destinée au dépôt et à la diffusion de documents scientifiques de niveau recherche, publiés ou non, émanant des établissements d'enseignement et de recherche français ou étrangers, des laboratoires publics ou privés. 
New insight of sedimentological and geochemical characterization of siliciclastic-carbonate deposits (Alveolina Limestone Formation, Graus-Tremp Basin, Spain).

Nouveau regard sur la caractérisation sédimentologique et

5 géochimique d'une série mixte "siliciclastique-carbonate" (la

formation des Calcaires à Alvéolines, Bassin de Graus-Tremp, Espagne).

Youri Hamon ${ }^{1}$, Remy Deschamps ${ }^{1}$, Philippe Joseph ${ }^{1}$, Daniel Garcia ${ }^{2}$, Emmanuelle Chanvry ${ }^{1,3}$

1: IFP Énergies nouvelles, 1 et 4 avenue de Bois-Préau, 92852 Rueil-Malmaison, France

2: Centre SPIN, Ecole Nationale Supérieure des Mines de Saint Etienne, and UMR CNRS 5600, 158 cours Fauriel, 42023 Saint-Etienne, France

3 : TOTAL SA, CSTJF, avenue Larribau, 64018 Pau, France

Corresponding author: youri.hamon@ifpen.fr

Keywords / Mots Clés :

Mixed facies; isotopes; elemental geochemistry; exposure; sequence stratigraphy; Ilerdian.

Faciès mixtes ; isotopes ; géochimie élémentaire ; émersion ; stratigraphie séquentielle ; Ilerdien. 


\section{Abstract:}

This article is a first attempt of combining sedimentological analysis and geochemical systematics of the Alveolina Limestone Formation as a tool to identify the major stratigraphic surfaces, and to improve the sequence stratigraphy interpretation. This formation is Early

5 Eocene in age and crops out in several well-exposed cliffs in the Serraduy - Roda de Isabena area (Graus-Tremp Basin, NE Spain). Within this succession, nineteen carbonate and siliciclastic facies have been identified and grouped in environmental facies associations (based on their vertical stacking and lateral relationships): 1) coastal plain; 2) clastic deltaic complex; 3) shallow carbonate inner-ramp; 4) mid-ramp; 5) outer-ramp; 6) reefal facies. The depositional architectures studied in the Serraduy area can be directly assessed on the field, and a $3 \mathrm{D}$ reconstruction is proposed. This enables us to build a synthetic depositional model and to identify five small-scale T/R cycles, bounded by different kinds of sedimentary discontinuities: angular unconformity, firmground, erosional surface... In parallel, geochemical analyses ( $\mathrm{C}$ and $\mathrm{O}$ isotopes, major, minor and trace elements) were carried out to help at hierarchizing the cycles and the boundaries previously identified. Four of them may be considered as major stratigraphic surfaces, corresponding either to regional-scale angular unconformity, or to exposure surfaces. The latter are characterized by a selective dissolution, a slight but sharp decrease in $\delta^{13} \mathrm{C}_{\mathrm{V}-\mathrm{PDB}}$ and in $\mathrm{Mg}, \mathrm{Fe}$ and $\mathrm{Sr}$ contents below the surface. The absence of typical sedimentary criteria of exposure (with the exception of these geochemical signatures) may be explained by short-term exposure, an arid to semi-arid climate, and a dominant low-magnesian calcite original mineralogy, precluding the development and the preservation of widespread vadose diagenetic products. A new sequence stratigraphy model for the Alveolina Limestone Fm is finally proposed and discussed. 


\section{Résumé:}

Cet article propose une étude intégrée, sédimentologique et géochimique, utilisée en tant qu'outil pour identifier les surfaces à valeur stratigraphique majeure et pour améliorer les interprétation de stratigraphie séquentielle. L'étude est réalisée sur la formation des

5 «Calcaires à Alvéolines », d'âge Eocène Inférieur qui affleure de manière spectaculaire dans la région de Serraduy - Roda de Isabena (Bassin de Graus-Tremp, NE de l'Espagne). Au sein de cette succession, dix-neuf faciès (tant siliciclastiques que carbonatés) ont été identifiés et regroupés en associations de faciès caractéristiques d'environnements de dépôt, en se basant sur leur empilement vertical et leurs relations latérales : 1) plaine côtière ; 2) complexe

10 siliciclastique deltaïque ; 3) rampe carbonatée interne peu profonde ; 4) rampe médiane ; 5) rampe externe ; 6) faciès récifaux. Les architectures de dépôt peuvent être directement évaluées sur le terrain et une reconstruction 3D est proposée. Ces points ont permis d'établir un modèle de dépôt synthétique et d'identifier cinq cycles élémentaires transgressifs/régressifs, délimités par différents types de discontinuités sédimentaires:

15 discordance, surface durcie, surface d'érosion... En parallèle, des analyses géochimiques (isotopes du carbone et de l'oxygène, géochimie des majeurs, mineurs et traces) ont été menées afin d'aider à la hiérarchisation des cycles élémentaires et de leurs limites. Quatre d'entre elles peuvent être considérées comme des surfaces stratigraphiques majeures, correspondant soit à des discordances angulaires d'échelle régionale, soit à des surfaces

20 d'émersion. Ces dernières se caractérisent par une dissolution sélective, une chute légère en $\delta^{13} \mathrm{C}_{\mathrm{V}-\mathrm{PDB}}$, ainsi qu'en $\mathrm{Mg}$, $\mathrm{Fe}$ et $\mathrm{Sr}$, sous la surface. L'absence de critère sédimentaire d'émersion (à l'exception de ces signaux géochimiques) pourraient être imputée à la faible durée et la faible amplitude des émersions, un climat aride à semi-aride et une minéralogie originale dominée par la calcite faiblement magnésienne, paramètres ayant limité la 
dissolution et le développement de produits diagénétiques vadoses. Un nouveau découpage séquentiel pour la Formation des Calcaires à Alvéolines est enfin proposé et discuté.

\section{Introduction}

Several authors have recently given new insights to an old problem: identification and hierarchization of sedimentary discontinuities [Clari et al., 1998; Hillgärtner, 1998; Immenhauser et al., 2000; Sattler et al., 2005; Christ et al., 2012a, 2012b, Hamon et al., 2013]. Sedimentary discontinuities are often important marker horizons that represent basic but essential features for sequence stratigraphy and paleoenvironmental reconstruction. However, their recognition in the sedimentary record, specifically in shallow-water carbonates may be difficult due to the variety of factors that may control their expression: hiatus duration, climate, original carbonate mineralogy and texture of the underlying facies. Moreover, these carbonate deposits are often affected by a strong burial diagenetic overprint that may hinder the original sedimentary and geochemical signal [Joachimsky, 1994; Clari et al., 1998; Moore, 2001; Christ, 2012b].

In the Graus-Tremp Basin, despite its name, the Early Ilerdian (early Eocene) Alveolina Limestone Formation is clearly a mixed carbonate-siliciclastic series, composed of bioclastic, bioconstructed and siliciclastic facies, showing a large diversity of facies and complex sedimentary architectures. The Alveolina Limestone Fm. has been extensively studied for microfacies characterization and its use for paleoclimate assessment or biostratigraphic purposes [Molina et al., 2003; Rasser et al., 2005; Scheibner et al., 2007; Pujalte et al., 2009]. Local-scale [Remacha and Zamorano, 1989; Payros et al., 2000] and regional-scale works on the sequence stratigraphy and stratigraphic architecture also exist [Eichenseer, 1988, 
Eichenseer and Luterbacher, 1992; Leturcq, 1999; Baceta et al., 2011]. Some significant differences (boundary's stratigraphic position, sequence types) exist between these works, that may be explain (at least partly) by the apparent lack of well-expressed sedimentary discontinuities and more specifically of exposure surfaces.

5 Based on spectacular outcropping conditions in the Serraduy area (located in the NorthWestern part of the Graus-Tremp Basin), this paper proposes an integrated approach, that aims at (1) describing the sedimentary facies and local architectures; (2) comparing these results with geochemical analyses ( $\mathrm{C}$ and $\mathrm{O}$ isotopes and element geochemistry) performed on samples covering the whole stratigraphic interval; (3) using these combined dataset to identify and hierarchize the different sedimentary discontinuities, and to discuss the puzzling absence of typical subaerial exposure-related criteria.

\section{Geological setting}

The study area (named Serraduy) is located in the Graus-Tremp Basin (Huesca Province), in the southern flank of the Spanish Pyrenees. This basin makes up the easternmost part of the South Central Pyrenean unit [Séguret, 1972; Mutti et al., 1988]. The latter corresponds to a set of allochthonous thrust sheets implying Mesozoic strata and Tertiary cover developed in piggyback sequences [Choukroune et al., 1968; Séguret, 1972; Ori and Friend, 1984; Munoz, 1992]. During the last Oligocene sequence, the South Pyrenean Zone has been thrusted over the present autochtonous Ebro Foreland Basin. The sedimentary cover shows: 1) Mesozoic (Jurassic to Late Cretaceous-Coniacian) pre-orogenic marine carbonates; and 2) a Santonian to Early Miocene, syn-orogenic succession that shows deposits from turbidites to alluvial environments. 
The sedimentary basins in the South Pyrenean Central Unit are bounded by three major thrusts rooted in the Triassic evaporitic decollement level: Boixols, Montsec, Sierras Marginales (Fig. 1A). The northernmost Boixols Thrust that corresponds to the Northern limit of the Graus-Tremp Basin was generated by the inversion of pre-existing E-W normal faults 5 [Roure et al., 1989] during the Late Cretaceous (Santonian), and sealed by the Aren Sandstones (Maastrichtian age). Southward, the Montsec Thrust was active during Early Eocene (Ypresian age), and corresponds to the limit between the Southern part of the GrausTremp Basin, and the Ager Basin. The Sierra Marginales thrust makes the boundary between the Ager Basin and the present-day Ebro foreland basin, and was active from Mid-Eocene to Oligocene. During Ypresian times, the Graus-Tremp basin was an E-W elongated basin controlled southward by the active Montsec Thrust.

In terms of palaeogeography during Palaeocene-Eocene times, the Graus-Tremp Basin is part of an elongated gulf opened westward into the Bay of Biscay, bordering the axial zone of the Pyrenees to the North, and located at paleolatitudes between $35^{\circ}$ and $38^{\circ}$ [Butterlin et al., 1993; Hay et al., 1999]. The climate system is mainly characterized by warm, generally ice-free conditions, culminating into the Early Eocene Climatic Optimum around 53,5 Ma (EECO; Sloan and Thomas [1998]; Zachos et al. [2001]). Interspersed through this warm interval were a series of dramatic events in surface temperature, called hyperthermals, lasting tens of thousands of years, followed by rapid declines towards baseline warming rates. The most prominent one is the Paleocene-Eocene Thermal Maximum (PETM, around 55.8 Ma), characterized in the Pyrenees by a temperature rise and an increase in seasonal rain and intraannual humidity gradient [Schmitz and Pujalte, 2007]. The studied interval takes place just after this PETM event.

The studied Alveolina Limestone Formation is part of the Early Tertiary fill of the basin (Figs. 1B and 2), characterized by the alternation of carbonate and siliciclastic facies. Late 
Palaeocene deposits are formed of continental or brackish-water series belonging to the Tremp Formation [Mey et al., 1968], passing westwards to shallow-water platform carbonates of the Navarri Formation [Garrido-Megias and Rios, 1972]. These formations are coeval with the end of the southward displacement of the innermost tectonic unit (Boixols), which itself is 5 capped by later Eocene deposits. A renewed marine incursion took place in the South Pyrenean Gulf at the beginning of the Eocene (Lower Ilerdian, 56-55 Ma), with the shallowwater and reefal carbonate deposits of the Alveolina Limestone Formation [Nijman and Nio, 1975; this study]. These deposits are onlapping from the south onto the continental deposits of the Tremp Formation [Fonnesu, 1984]. At that time, the central tectonic unit of Montsec also began to move southwards. Middle and Late Ilerdian times are characterized by the sedimentation of the Riguala Marls [Tosquella, 1988], passing upward into the La Puebla Limestone Formation [Cuevas-Gozalo et al., 1985] corresponding to a series of marly limestones, deposited in a shallow shelf environment. The overlying Roda Sandstone Formation (late Ilerdian to Cuisian; Cuevas-Gozalo et al. [1985]) is made up of six prograding sand bodies which are interbedded with nummulitic marls [Crumeyrolle et al., 1992]. The uppermost part of the Roda Sandstone unit is characterized by a transgressive sequence composed of marl/limestone beds (Morillo Limestone Formation; Cuevas-Gozalo et al. [1985]).

The studied Alveolina Limestone Formation covers two distinct Alveolina biozones [Hottinger, 1960; Serra-Kiel et al., 1994] (Fig. 2): Alveolina cucumiformis (SBZ5; Gradstein et al. [2004]) and Alveolina ellipsoidalis (SBZ6; Gradstein et al. [2004]). This formation is attributed to the Lower Ilerdian period [Payros et al., 2000; Molina et al., 2003]. 


\section{Material and methods}

The studied area is a square of $3 \mathrm{~km}$ by $3 \mathrm{~km}$, centered on the village of Serraduy del Pon. The studied Alveolina Limestone Formation is cropping out in several well-exposed cliffs. Ten detailed sedimentological sections were described at the 1/100 scale (see Fig. 1C for 5 location).

Petrographic analyses were carried out on 155 thin sections, with a Nikon Eclipse LV100 POL microscope. All thin sections have been stained with alizarin red-S to differentiate carbonate minerals (aragonite, calcite are stained, while dolomite remains unstained; Dickson [1966]) and potassium ferricyanide for distribution of ferrous iron. In order to estimate the amount of the different allochems, point counting on scanned thin sections has been performed, using JmicroVision Image analysis system [Roduit, 2008]. The point counting was performed using a random selection of points, and stopped based on a stochastic criterion (when the percentages are getting stable, the counting can be stopped). Oxygen $(\mathrm{O})$ and carbon (C) isotope analysis have been performed on 84 samples, distributed over three representative sections of the Serraduy area (sections AB, H, N). Samples consists in largerforaminiferas (Alveolina and Nummulites), apart for facies in which they are absent (facies B1, B2 and B3). In the latter case, samples correspond to bulk, dominated by Microcodium debris. Analyses were made at the Institute of Geology and Mineralogy of Erlangen (Germany) with the following procedure. Carbonate powders were reacted with $100 \%$ phosphoric acid (density $>1.9$, Wachter and Hayes [1985]) at $75^{\circ} \mathrm{C}$ using a Kiel III online carbonate preparation line connected to a ThermoFinnigan 252 mass-spectrometer. All values are reported in per mil relative to $\mathrm{V}-\mathrm{PDB}$ by assigning a $\delta^{13} \mathrm{C}$ value of $+1.95 \%$ and a $\delta^{18} \mathrm{O}$ value of $-2.20 \%$ o to NBS19. Reproducibility was checked by replicate analyses of laboratory standards and is better than $\pm 0,02(1 \sigma)$. 
Major, minor and trace element analyses have been performed for section $\mathrm{N}$ and composite section $\mathrm{AB}$ (64 samples). As sample splits of 0.25 and $0.5 \mathrm{~g}$ are required for this kind of analyses, sampling was performed on bulk matrix. Analyses were made at the Centre SPIN (Ecole Nationale Supérieure des Mines de Saint- Etienne) with the following procedure. The analyses were made by Inductively Coupled Plasma Emission Spectrometry (ICP-AES) after HF digestion for major and minor elements but $\mathrm{Si}$, and selected trace elements ( $\mathrm{Sc}, \mathrm{V}, \mathrm{Zn}, \mathrm{Sr}$, $\mathrm{Y}, \mathrm{Ba})$. A subset of the samples, only from section $\mathrm{AB}$, was further analyzed for major elements by X-rays Fluorescence on glass beads to measure $\mathrm{SiO}_{2}$ contents. Both analytical procedures were calibrated against international geostandards, and analytical accuracy is estimated in the $5 \%$ range. A multivariate statistical analysis has been performed on this dataset. A Principal Component Analysis (PCA) was carried out on the measured variables using their correlation matrix (Wold et al. [1987]) for a complete description of this method). Secondly an Agglomerative Hierarchical Clustering (AHC) was performed to help classifying our analyses into hierarchical clusters [Kaufman \& Rousseeuw, 1990]. Statistical analyses were performed with the software XLStat.

\section{Facies analysis}

Nineteen sedimentary facies were defined by their texture, their constituents, their sedimentary structures, their fossils and/or trace fossils (when present). Several papers already described and interpreted similar macro- and microfacies in and outside the studied area [Plaziat, 1975; Plaziat, 1984; Eichenseer, 1989; Eichenseer and Luterbacher, 1992; Payros et al., 2000; Rasser et al., 2005; Scheibner et al., 2007]. These facies were grouped into six facies associations, defined and then attributed to a specific depositional environment on the basis of their constituent facies, their vertical stacking, their lateral facies change and their 
overall geometry [Wilson, 1975; Purser, 1980; Scholle et al., 1983; Tucker and Wright, 1992]. As this Ilerdian interval is dominated by larger foraminifera (Alveolina, Orbitolites, Nummulites, Assilina...), we also used the analyses of Hottinger [1997], Geel [2000] and Rasser et al. [2005] to arrange the depth zonation of the larger-foraminifera facies. The facies 5 are detailed and interpreted in the following part.

\section{Facies association A: Coastal plain}

\section{Description}

This facies association is composed of four facies. Facies A1 is a reddish, polygenic, heterometric and azoic clast-supported conglomerate, with a medium to coarse-grained sandstone matrix (Fig. 3A). It forms metre to plurimetre-thick erosive, fining-upward sheets, filling wide and low-relief scours (15-20m wide, for 1-2 m deep). This facies often exhibits trough-cross bedding associated to megaripples migrating toward the South-West. This facies is generally overlain by the facies A2, a fine- to medium-sandstones, with Miliolids and rare bioclasts. It consists in decimeter-thick beds with trough-cross bedding and planar laminations. Facies A3 is composed of laminated, grey to reddish marly siltstones, with decimeter-thick level with abundant root traces and whitish carbonate concretions. Finally, facies A4 is a silty limestone facies, characterized by a wackestone texture with abundant small Miliolids, rare ostracods, ostreid bioclasts and Alveolina.

\section{Interpretation}

The dominant siliciclastic sedimentation, the presence of root traces and, when present, the restricted character of the faunal content (ostreids, Miliolids) suggest very proximal, continental to littoral environments. Indeed, facies A1-A2 were interpreted as braided streams, part of wave-dominated braid deltas by Eichenseer and Luterbacher [1992] or as 
representing the proximal parts of a fluvial megafan by Schmitz and Pujalte [2007]. The presence of Miliolids and rare ostreid fragments in the facies A2, indicates a littoral, restricted marine environment in which these braided stream prograded. The facies A3 may be interpreted as coastal plain deposits, as indicated by the planar lamination (suggesting low hydrodynamism regime and decantation process) and bioturbation [Reading, 1996]. Locally, the presence of root traces and carbonate concretions indicates episodic development of paleosoils. Finally, the presence of ostracods and small benthic Miliolids in the facies A4 are indicators of restricted marine conditions, possibly brackish marshes [Flügel, 2004; Rey and Bousquet, 1981].

\section{Facies association B: Deltaic complex}

\section{Description}

This facies association consists of four mixed sandy-carbonate facies. Facies B1 is a bioturbated (Thalassinoides) fine to medium-grained sandstone, often organized in low-angle inclined stratifications, forming lobate structures up to $10 \mathrm{~m}$ in thickness, with a sharp erosional base (Figs. 3B and 3C). The bioclastic fraction (between 20 to 40\%) is composed of Microcodium, pelecypod, Miliolid debris, associated with micritic intraclasts (Fig. 4A and 4B). A micritic matrix is occasionally observed. Facies B2 is a clayey facies, interfingered with facies B1 in the periphery of the lobes, forming decimeter- to meter-scale alternations of marls and fine-grained sandstones (Fig. 3B and 3C). Lignite fragments and burrows (both horizontal and vertical) are frequently observed in these two facies. Often associated to the previous ones, the facies B3 is composed of a sandy and bioclastic limestone. It forms smallscale channel fills, that exhibit sigmoidal cross-stratifications with current ripples at their top. Bioclasts are highly fragmented and show a large diversity (Miliolids, Nummulites, rare 
Alveolina, echinoid debris, pelecypods, gastropods and Dasycladacean stem fragments, Fig. 4C). Finally, facies B4 is a gastropod-dominated wackestone, with some plane-parallel beds and a slight nodular aspect. Dasycladacean stem fragments associated with many Miliolids and rare fragmented, and micritized Alveolina and Orbitolites are also observed (Fig. 4D).

\section{Interpretation}

The absence of any open marine organisms and the abundance of detrital quartz suggest sedimentation in a restricted and very proximal environment. The lobate geometry, the internal sigmoidal structures and the erosional base of facies B1, point to terminal lobes of a fluvial-dominated delta, supplied from the North by distributary channels [Middleton, 1991; Walker, 1992]. The stratigraphic relationships between facies B1 and B2 point to a lateral facies change. B2 is thus interpreted as fringing shaly deposits, immediately downstream of B1 [Rey and Bousquet, 1981]. However, the sigmoidal cross-stratification and the mixed sandy-bioclastic infill tend to indicate a reworking by tidal currents. Facies B3 is interpreted as distributary channels (channelized structures) supplying the B1-B2 lobes. Finally, the bioclasts' association observed in B4 (mainly monospecific gastropods and green algae), suggests deposition in a calm, restricted environment such as interdistributary restricted ponds or mudflats [Rey and Bousquet, 1981; Rasser et al., 2005].

\section{Facies association C: Shallow inner ramp}

\section{Description}

This facies association is composed of three carbonate and one marly facies. Facies $\mathrm{C} 1$ is an Alveolina and Orbitolites dominated wackestone to packstone, showing a highly nodular bedding. Allochems are moderately fragmented, micritized, and dominated by Alveolina (8090\%), and a varying amount of Orbitolites (0-15\%) (Fig. 4E). Miliolids, echinoid, green algae 
debris, and a few micritic intraclasts are also observed (Fig. 3F). Lucina in living position are commonly found. Facies C2 is a marly dominated facies, closely interstratified with C1 facies. Lucina, ostreids and rare Alveolina can be observed. Facies C3 is made up of megaripples, with opposite current directions, filling large-scale channels. The microfacies is

5 a micro-grainstone dominated by micritic peloids and Miliolids, a few echinoid debris and rare micritized larger-foraminifera (Fig. 4F).

In the Serraduy area, a large erosive channelized structure crops out, filled by a submarine dune bedform characterized by large inclined stratifications, with a dominant current direction towards the East (facies C4; Figs. 3D and 3E). The latter is $300 \mathrm{~m}$ long and ranges from 2 to $15 \mathrm{~m}$ in height. It is composed of several accretionary units, separated by minor erosional surfaces and can be divided into two sub-facies: a grainstone characterized by moderately fragmented Alveolina, Orbitolites and red algae as the most prominent components; a wellsorted micro-grainstone, dominated by Miliolids (10-15\%) and rounded micritized undetermined bioclasts and intraclasts (20-25\%) (Fig. 4G).

\section{Interpretation}

The environmental interpretation of medium-grained Alveolinid-Soritid facies with nodular aspect is still controversial in Eocene ramps (low-energy beaches, sea grass-covered grain flats, shallow subtidal ramp; see Beavington-Penney and Racey, 2004 and references herein). The high abundance of Orbitolites in the facies $\mathrm{C} 1$ suggests a very proximal setting, in the shallowest parts of carbonate platforms [Hottinger, 1997; Geel, 2000]. As suggested by Rasser et al [2005] or Eichenseer and Luterbacher [1992], this facies may represent a beach environment. The muddy texture of the facies, suggests low-energy beaches that may border a calm lagoonal environment, represented by C2 facies. 
On the contrary, the grainy texture and the high fragmentation observed in the $\mathrm{C} 3$ facies point to high energy conditions. Erosive base and sedimentary structures are thought to be formed by the migration of 3D-megaripples localized in a tidal channel (two opposite current directions), cutting through the previously described inner platform facies. High content in

5 Miliolids also suggests a proximal platform interior setting [Geel, 2000].

The facies C4 is interpreted as a large-scale channel filled by a prograding megadune, as it is confined and probably elongated within the channel [Olariu and al., 2012]. A tidal origin is proposed by Eichenseer [1988] and Eichenseer and Luterbacher [1992] on the basis of the channelized morphology, the geometry and orientation of the clinoforms that prograded eastwards. The dominance of Alveolina, Orbitolites and red algae suggests a deposition in the open waters of an inner- to mid-platform setting [Scheibner et al., 2007]. This channel filled by tidal dunes prograding into a lagoonal environment suggest a tidal inlet.

\section{Facies association D: Mid-ramp}

\section{Description}

Two carbonate facies are described in this facies association: Facies D1 is a silty wackestone dominated by fragmented Alveolina but entire globose Nummulites (Fig. 4H), associated with ostreids (generally encrusting top of beds) and echinoid debris, lacking sedimentary structures. No peculiar changes in the size or morphology of the larger-benthic foraminifera was observed. Facies D2 is a silty, Operculina-rich wackestone (Fig. 4I), moderately bioturbated, without any sedimentary structures. This facies occurs rarely and is generally interstratified with Facies D1. 


\section{Interpretation}

Facies D1 is characterized by the mixing of two types of larger-foraminifera, which suggest two different environments [Geel, 2000]. Rasser et al. [2005] observed a similar facies in the Ilerdian Minerve section (Southern France) and interpreted it as an offshore-transport of Alveolina (from proximal area) into a more open and distal environment (presence of Nummulites). Such a mixing may be indicative of a mid-ramp setting. Eocene nummulitic accumulations have been studied by Mateu-Vicens et al. [2012], who proposed a mass flow origin. In the facies D1, nummulites are mostly entire, with very few nummulithoclasts and no sedimentary strucutres are observed, with suggest in situ deposition. Globose Nummulites are generally associated with the basal part of the euphotic zone to the shallowest part of the mesophotic zone [Hottinger, 1997; Pomar, 2001, Pomar et al., 2014]. Geel [2000] proposed a depth range of 10 to $30 \mathrm{~m}$ for small and medium-sized, lens-shape Nummulites (euphotic zone of Pomar [2001]). Similarly, the faunal composition of D2 (dominance of Operculina) suggests a deposition in an open marine, mid-ramp setting [Hottinger, 1997; Scheibner et al., 2007]. Operculina is thought to be less dependent on coralline algae symbionts for food, and is therefore inferred to have had a wider environmental range than the other Nummulitids, commonly associated to the mesophotic zone [Hottinger, 1997; Boudagher-Fadel, 2008]. Such conditions commonly correspond to a depth range of 40 to $80 \mathrm{~m}$ of water depth [Pomar, 2001] but they may also occur in dense seagrass meadows or in case of important turbidity [Pomar et al., 2014]. The absence of miliolids or green algae fragments do not support such hypothesis for facies D2, that may be associated to the lower part of the mid-ramp. 


\section{Facies association E: Outer-ramp}

\section{Description}

This association generally consists in weathered moderately bioturbated wackestone beds (E1), pluridecimetric in thickness, alternating with marly facies (E2). The wackestone beds

5 are dominated by Assilina, and subordinate Operculina, Nummulites, echinoid and crinoid debris and frequent glauconite grains associated with a minor lithified top surface (Fig. 4J). Again, no peculiar changes in the size or morphology of the larger-benthic foraminifera was observed.

\section{Interpretation}

The presence of Assilina and Operculina, the muddy texture and the absence of innerplatform foraminifera point to a mesophotic to oligophotic outer-ramp environment, below the fair-weather wave base. The presence of crinoid debris (photo-independent biota) or Nautiloids (described by Leturcq [1999], not observed in this study) also supports such hypothesis. Finally, the alternation of marly and carbonate facies with the occurrence of early lithified and glauconitic surfaces also suggest a low production rate. This is consistent with the interpretation of Rasser et al. [2005], Scheibner et al.[2007] or Scheibner and Speijer [2008].

\section{Facies association F: Reefal facies}

\section{Description}

At different intervals of the Lower Ilerdian succession, coral-dominated build-ups (averaging hundred meters of lateral extent and less than ten meters in height) are organized into three 
parts (Figs. 3F, 3G and 3H). The core (and base) of the build-up is generally dominated by metric alternations of C1 (Alveolina and Orbitolites wackestone / packstone) and F1 facies (Alveolina and coral-dominated wackestone). The latter shows decimetric egg-shaped coral "bushes" composed of bulbous, tabular corals (Poritidae) and red algae (Fig. 4K), in a

5 surrounding matrix composed of $\mathrm{C} 1$ facies. Progressively, metric beds of facies $\mathrm{F} 2$ are observed and finally forms the upper part of the build-up. Facies F2 is a framestone composed of bulbous and tabular corals, red algae and a few occurences of encrusting foraminifera Solenomeris, are observed. The edges of the build-ups may show lateral accretionary sets, made up of reworked bioconstructed-derived material (s.s.), mixing all the previously described facies.

A second type of reefal facies has been observed in Section $\mathrm{N}$, forming metre-thick biostromes, lacking a rigid framework (Fig. 3H). It is composed of a bindstone (to framestone) mainly composed of bulbous Solenomeris (encrusting foraminifera, Acervulinidae group) associated with red algae, rare bioclasts (echinoids, lamellibranches) and a micritic matrix (facies F3; Fig. 4L).

\section{Interpretation}

The faunal content of F1 and F2 points to a reefal environment. Recently, Morsilli et al. [2012] and Pomar et al. [2014] demonstrated the existence of Late Eocene, coral-dominated build-ups, in relatively deep, mesophotic zone and relatively nutrient-rich water. These buildups are characterized by non-framework corals, with sparse coral colonies in a bioclastic, muddy matrix. Corals are also associated with red algae, bryozoans, mesophotic large-benthic foraminifera, serpulids and sponges. Finally the build-ups are completely encased in clay.

In our case study, the main body of the build-ups is made of a coral-dominated frame-built reef, without any bryozoans or sponge and very rare fragments of serpulids. The associated 
matrix is an Alveolina and Orbitolites wackestone to packstone. The presence of Soritids and the absence of mesophotic/mesotrophic larger-benthic foraminifera (Nummulites, Operculina...) in the matrix suggests that these build-ups developed in a shallow inner- (or mid-ramp) setting [Scheibner et al., 2007; Morsilli et al., 2012]. This seems to be confirmed

5 by the build-up association with facies $\mathrm{C} 1$, rather than deep facies. The internal architecture of the build-ups (abundant association of red algae and pioneer forms of corals at the base versus a higher diversity of branching, bulbous and lamellar corals at the top) may therefore indicate an evolution from mesotrophic environmental conditions to more oligotrophic conditions, in the euphotic zone [Tucker and Wright, 1992; Wood, 1999]. The absence of a detritic fraction (silts or clay) also suggests such oligotrophic/euphotic conditions. Finally, these build-ups are constantly eroded and the reworked material is accumulated laterally. In the facies F3, the absence of diversified forms of corals and the abundance of Solenomeris (pioneer, tolerant bioconstructors) suggest less optimal ecological conditions that lead to the reduction of competition for substrate encrustation (decrease of light intensity and hydrodynamic energy).

They generally extend into deeper water than coral reefs, even in turbid environments [Perrin, 1992; Bosellini and Papazoni, 2003]. This is confirmed by the presence of a micritic matrix, that may indicate a low-energy environment, probably more turbid (outer periphery of lagoon or external margin of carbonate platform for Plaziat and Perrin [1991]).

\section{Local sedimentary architectures and sequence stratigraphy}

In Serraduy, due to the good outcrop quality, the sedimentary architectures were directly assessed on the field, by following the main discontinuities (erosional surfaces, hardgrounds). Thus, a 3D model illustrating the general architecture of the Alveolina Limestone in the Serraduy area is proposed in Figure 5. These observations enable us to propose a synthetic 
depositional profile (Fig. 6A) with a proximal deltaic system (Facies Associations A and B) prograding into an inner ramp setting (FA. C), passing downstream to a mid (FA. D and F) then outer ramp setting (FA. E), and to identify small-scale transgressive/regressive cycles [Embry, 1993]. A purely descriptive and time-independent nomenclature is applied to 5 designate the different scales of sedimentary cycles described in this study. The finest elementary cycles are called generically "small-scale cycles" (sensu Strasser and Hillgärtner [1998]), bounded by sedimentary discontinuities: sharp changes of facies, hardgrounds, erosional truncations... (Fig. 6B).

The first small-scale cycle (Fig. 6B) is limited at its base by a major, low-relief erosive surface, correlated over the whole studied area (S0). It is overlain by some metre-thick sheets of conglomerates (facies A1), corresponding to the Claret Conglomerate [Baceta et al., 2011]. It is followed by bioclastic sandstones (facies A2), and bioturbated siltites (facies A3). Bioclastic shallow inner-ramp facies (A4 and $\mathrm{C} 1$ ) are onlapping over a ravinement surface, suggesting a trangressive trend. In the Northern part of the area (section N; Fig. $3 \mathrm{H}$ and 5), a coral-dominated build-up developed, interstratified with this shallow inner-ramp facies. It is composed of Poritidae, and red algae boundstones (facies F1 and F2) with facies C1 at the base, grading upward into coral-dominated boundstones (facies F2). This could suggest a progressive deepening and improvement of the ecological conditions associated to the end of the transgressive trend, followed by an increasing coral growth (that forms the bulk of the bioherm) during the highstand conditions [Wood, 1999; Schlager, 2005]. In the Southern part of the area (sections $\mathrm{C}$ and F; Fig. 5), the shallow inner-ramp facies (facies C1) are overlain by a highly bioturbated and glauconitic thin interval $(40 \mathrm{~cm})$ of facies D2, which may represent the maximum flooding of the cycle. The regressive part of the cycle is eroded by the unconformity S1. 
The second small-scale cycle (Fig. 6B) is bounded at its base by the surface S1, an erosive angular unconformity forming a large-scale (100 m wide, 4-5 m thick) channelized unit (Fig. 3E and 5), filled by facies $\mathrm{C} 3$. The preservation of the tidal channel fill suggests a positive accommodation, related to a transgressive trend. Upon it, a complex deltaic system

5 developed, composed of at least seven sandy lobes (facies B1-B2) (Fig. 3E and 5), supplied from the North by multiple distributary channels (facies B3). Their spatial distribution is partly governed by a prograding trend and partly by stratigraphic compensation processes (i.e. the lobes are emplaced in negative topography between the previous ones). This interval may correspond to the regressive part of the cycle.

The third small-scale cycle (Fig. 6B) is bounded at its base by the surface S2, corresponding to a deeply scoured channel (sections $\mathrm{AB}, \mathrm{C}, \mathrm{F}$ and I; Fig. 3D, 3E and 5). A large bioclastic tidal bar (facies C4), passing laterally to a marly, Lucina-rich facies (C2) filled this structure (section D). Outside of the channel, some shallow, inner-ramp facies (C1) are observed. The preservation of the tidal channel fills suggests a positive accommodation, until a maximum marked by the preservation of the topset in the uppermost part of the bar [Emery and Myers, 1996]. This level is successively overlain by facies C2 and C1 (lagoonal and low-energy beaches), pointing to a prograding trend, that ended by a new discontinuity (surface S3).

Subsequently, the fourth small-scale cycle (Fig. 6B) is characterized by the development of several build-ups (sections N, G and F; facies F1-F2) interfingered with inner- (facies C1) to mid-ramp facies (facies D1) (Fig. 3F, 3G and 5). This points to a general improvement of the ecological conditions of the depositional environment [Wood, 1999; Brock et al., 2008], with a decrease of the detrital influx (confined to the most proximal regions) and an increase of the hydrodynamism associated to the transgressive phase of the cycle. The latter is followed by the outer-ramp facies (E1 and E2), and capped by mid-ramp facies (D1) which may point to a 
new prograding trend. The fourth cycle ends with a mineralized and glauconite-rich surface (S4).

The fifth (and last) cycle (Fig. 6B) is composed at its base by outer-ramp facies (facies D2, E1, alternating with marly facies E2). In the Northern part of the area, a meter-scale Solenomeris reef-mounds is observed (facies F3) (section N; Fig. 3H and 5). The absence of corals and the large development of Solenomeris point to a deterioration of the ecological conditions, that could be linked to the stability of water masses during the end of the cycle [Lukasik and James, 2003]. The succession is topped by a mineralized and glauconite-rich surface, encrusted by Solenomeris and Bryozoans (surface S5).

At this step, due to the absence of clearly marked exposure criteria and the lack of unequivocal stacking pattern in this shallow ramp setting, it is difficult to hierarchize these small-scale cycles and to describe larger-scale trends. To overcome these problems, complementary geochemical analysis have been performed and are presented hereafter.

\section{Geochemistry}

\section{Isotope geochemistry}

The results of $\mathrm{O}$ and $\mathrm{C}$ isotope analyses for the Serraduy area (Table 1 - Supplementary Material) have been plotted in $\delta^{18} \mathrm{O}$ versus $\delta^{13} \mathrm{C}$ cross-plots (Fig. 7) and vertically along the sedimentary logs (Fig. 8). As a general point, these isotopic values are characterized by a good covariance between the $\delta^{18} \mathrm{O}_{\mathrm{V}-\mathrm{PDB}}$ and $\delta^{13} \mathrm{C}_{\mathrm{V}-\text { PDB }}$ (Fig. 8) and possibly by the inverted Jshaped curve [Lohmann, 1988] (Fig. 7). Three fields of isotopic values can be distinguished.

A first field is characterized by isotopic values ranging from $-4.10 \%$ o to $-2.37 \%$ or $\delta^{18} \mathrm{O}_{\mathrm{V}-\mathrm{PDB}}$ and $1,12 \%$ to $2,59 \%$ for $\delta^{13} \mathrm{C}_{\mathrm{V} \text {-PDB }}$ (Fig. 7). They corresponds to larger-foraminifera samples and are spread in the cycles 1, 3, 4 and 5 (Fig. 8). The $\delta^{13} \mathrm{C}_{\mathrm{V} \text {-PDB }}$ values fall in the range of the 
isotopic signatures of the Lower Eocene marine calcite from Veizer et al. [1999] (grey domain in Fig. 8), whereas the $\delta^{18} \mathrm{O}_{\mathrm{V} \text {-PDB }}$ values are shifted toward more negative signatures.

The second field of isotopic values is characterized by negative $\delta^{18} \mathrm{O}_{\mathrm{V}-\mathrm{PDB}}$ values $(-4.19 \%$ o to $-3.12 \%$ ) and slightly negative to positive $\delta^{13} \mathrm{C}_{\mathrm{V}-\mathrm{PDB}}(-1.69 \%$ o to $1,28 \%$ ) (Fig. 7 ). These samples also correspond to larger-foraminifera, but are located below peculiar sedimentary discontinuities. Thus, discontinuities $\mathrm{S} 1$ and $\mathrm{S} 3$ are marked by a slight shift toward $\delta^{13} \mathrm{C}_{\mathrm{V}-\mathrm{PDB}}$ negative values in section $\mathrm{N}$ (Fig. 8). This slight but sharp decline is only observed below S3 in the other studied section ( $\mathrm{AB}$ and $\mathrm{H}$ ). Apart from this slight negative shift in the vicinity of bounding discontinuities, no specific vertical variations are observed along one single cycle (Fig. 8).

Finally, the third field of data displays strongly negative values, both in $\delta^{18} \mathrm{O}_{\mathrm{V}-\mathrm{PDB}}(-6.68 \%$ o to $-4.91 \%$ ) and in $\delta^{13} \mathrm{C}_{\mathrm{V} \text {-PDB }}(-6.41 \%$ o to $-4.08 \%$ ) (Fig. 7 ). These samples are located in the siliciclastic-dominated interval (cycle 2; Fig. 8), where the carbonate fraction mainly corresponds to Microcodium debris.

\section{Elemental geochemistry}

The results of the elemental values for the Serraduy area (Table 1 - Supplementary Material) have been analysed through a multivariate statistical analysis: the Principal Component Analysis (PCA). PCA is broadly used in geochemical studies [Azevedo et al., 2008; Marques

et al., 2008 and reference herein]. In the case of a geochemical data matrix, each vector shows that the data spread according to their geochemical affinity and provenance. A first PCA was done on the whole dataset (Figs. 9A and 9B), excluding the Si variable, as Si analyses were carried out only on a subset of samples, from section AB. A second PCA was then performed on this specific subset, including all the variables (Fig. 9C). 
The PCA (Fig. 9) and their associated Pearson correlation matrix (Table 2) show several relationships between key parameters. In the first PCA (Fig. 9A; Table 2A), several strong positive correlations are highlighted, such as $\mathrm{Al}_{2} \mathrm{O}_{3}$ with $\mathrm{TiO}_{2}, \mathrm{Na}_{2} \mathrm{O}$ and $\mathrm{K}_{2} \mathrm{O}$. In the $\mathrm{PCA}$ circle of correlation (Fig. 9A), these positively correlated variables tend to be close.

5 Moreover, the second PCA (Fig. 9C; Table 2B) shows that these variables are also strongly correlated with $\mathrm{Si}_{2} \mathrm{O}$. Negative correlations between $\mathrm{CaO}$ and these variables $\left(\mathrm{Al}_{2} \mathrm{O}_{3}, \mathrm{TiO}_{2}\right.$, $\mathrm{Na}_{2} \mathrm{O}$ and $\mathrm{K}_{2} \mathrm{O}$ ) are observed in the PCA circle of correlation, where negatively correlated variables tend to be diametrically opposed in the projections (Fig. 9A; Table 2A). Finally, $\mathrm{Fe}_{2} \mathrm{O}_{3}$ and $\mathrm{MnO}$ are significantly negatively correlated with $\mathrm{CaO}$, whereas $\mathrm{MgO}$ and $\mathrm{SrO}$ are not correlated with $\mathrm{Ca}$. On the other hand, $\mathrm{Fe}_{2} \mathrm{O}_{3}, \mathrm{MnO}$ and $\mathrm{MgO}$ seems partly correlated with $\mathrm{Al}$ and $\mathrm{Si}$ (and the abundance of siliciclastics).

These latter correlations can also be illustrated by the vertical plots of elemental contents along the sedimentary $\log$ s of sections $\mathrm{AB}$ and $\mathrm{N}$ (Fig. 10). The analysed samples are characterized by moderate to low content of $\mathrm{Mg}$, mainly ranging from 5500 to $9500 \mathrm{ppm}$ in both sections (Fig. 10). The $\mathrm{Mg} / \mathrm{Ca}$ molar ratio calculated for carbonate samples (Table 1 Supplementary Material) are typical of low-Mg calcites [Carpenter and Lohmann, 1992; Sherman et al., 1999]. $\mathrm{Fe}_{2} \mathrm{O}_{3}$ vary from 0 to 5700 ppm in section $\mathrm{N}$ and from 400 to $7700 \mathrm{ppm}$ in section $\mathrm{AB}$ with the same trends and positive anomalies (up to $21000 \mathrm{ppm}$ ) than for $\mathrm{Mg}$. $\mathrm{A}$ slight enrichment both in $\mathrm{Mg}$ and $\mathrm{Fe}$ is observed in the siliciclastic-dominated facies (facies B1 to B4) of cycles 2 and 3 (Fig. 10), which could be explained by several hypothesis: presence of biotite, and presence of small dolostone clasts coming from reworked layers of Garumnian Fm. deposits (not observed in the studied thin section). In section AB, a few positive anomalies (up to $15000 \mathrm{ppm}$ ) are observed, corresponding to basal lags just above erosive surfaces (S1 and S2; Fig. 10). 
MnO content is relatively similar in the two studied sections (Fig. 10). It is low to moderate, varying from 50 to $250 \mathrm{ppm}$ in carbonate facies, and from 300 to $800 \mathrm{ppm}$ in siliciclasticdominated facies. No peculiar relationship with stratigraphic surfaces is observed (Fig. 10). However, they are clear sequence-related differences: a substantial $\mathrm{MnO}$ enrichment is

5 observed in the siliciclastic-dominated facies of the cycles 2 and 3 (Fig. 10). It may be related to the abundance of soil-derived particles (Krumbein and Jens, 1981; Woody et al., 2014) or eventually to Microcodium clasts (Kosir, 2004).

SrO content exhibits low and slightly fluctuating values (mean 672 and 750 ppm, respectively in sections $\mathrm{N}$ and $\mathrm{AB}$; Fig. 10). The siliciclastic-dominated facies display the lowest values (Fig. 10). SrO content of the carbonate facies is characterized by significantly lower values in cycle 1, compared to cycles 3, 4 and 5. These values are in line with those of low-Mg calcites [Carpenter and Lohmann, 1992; Sherman et al., 1999].

Finally, the large majority of the analyzed samples shows low $\mathrm{Na}$ contents. The latter are more important in siliciclastic-dominated facies (300 to $1100 \mathrm{ppm}$ ) than in carbonate ones (150 to $400 \mathrm{ppm}$ ). Higher values are observed in carbonates at the base of section $\mathrm{N}$, ranging between 600 to $900 \mathrm{ppm}$. A shift toward minimum values is observed below the surface S1 in section $\mathrm{N}$ and below S3 in both sections (Fig. 10).

\section{Cluster analysis}

The PCA carried out previously also enables us to look at the data on a two-dimensional map and to identify trends, through a proximity analysis of the different points (Fig. 9B). On this figure, a dense cloud of points is observed near the center of the circle. It is composed of carbonate-dominated samples, including the samples located below discontinuities S1 and S3. A second group of points may be observed, corresponding to the siliciclastic-dominated samples (facies B1, B3 and B4). Finally, a few atypical points are scattered away from these 
groups (C9, C11, N1, N20 and B9) and correspond to lag deposits, situated just above erosional surfaces.

The interpretation of the dense point cloud directly on the PCA circle may be tricky as the points situated near the circle center are generally badly represented in the factors space (Fig. 9B). An Agglomerative Hierarchical Clustering (AHC) was therefore performed to help classifying these specific analyses (carbonate-dominated samples, excluding the siliciclasticdominated samples) into hierarchical clusters. The AHC works from the dissimilarities between the objects to be grouped together. The results are illustrated in the dendrogram of Fig. 10, wherein the cluster distance on the vertical axis represents the level of association between groups of observations (data); short distance values indicate the greatest similarity between variables. Three groups may be isolated. The first (green color) group is made of samples of lag deposits (C9, N1 and B9) and is more heterogeneous than the other ones (within-class variance a lot higher for the first group). The samples PA1 and B2 were not identified in the PCA circle but correspond to the very base of carbonate beds and may be associated to lag deposits. The third group (blue color) corresponds to the major part of the carbonate samples, whereas the second group (purple color) is composed of carbonate samples located in the vicinity of discontinuities S1 (samples N10, N12, N13, N14) and S3 (samples B22, B23, B24, N23, N24). Samples N3 and N8 are located in the cycle 1 (facies F1 and F2), whereas the sample N19 corresponds to B4 facies in cycle 3. The origin of this clustering will be discussed in the following part of the article with also the specificity of sample C11 that appears as a single value (in black). 


\section{Discussion}

\section{Insight from isotope geochemistry}

The isotopic values in the Serraduy succession are in the same range than those in the Upper Paleocene - Lower Eocene limestones in the Ermua and Zumaya sections (Basque Country,

5 Northern Spain; Schmitz et al. [1997]), in the Esplugafreda section (Graus-Tremp Basin; Schmitz et al. [1997]; Schmitz and Pujalte [2003]) or in the Campo section [Molina et al., 2003]. These previous isotopic studies have shown that the whole rock samples of limestone and calcite-rich marls give reliable $\delta^{13} \mathrm{C}$ results. In our case study, apart from the samples taken in the siliciclastic-dominated interval, the isotopic data comes from analyses of Alveolina and a few Nummulites. These two genus are both epifaunal and may spanned in nearly comparable paleoenvironments (lagoon to mid-shelf, warm, normal marine water; Boudagher-Fadel, 2008). This similarities may prevent a significant differential fractionation due to the vital effect of these benthic larger-foraminiferas (Schmiedl et al., 2004; Friedrich et al., 2006). This seems to be confirmed by the $\delta^{18} \mathrm{O}$ versus $\delta^{13} \mathrm{C}$ cross-plots where the values of both type of samples fall in the same range of values (first field of values, Fig. 7). The isotopic variations observed between the different field of values may therefore be considered as diagenetic rather than original.

As it was presented previously, three field of isotopic values have been identified. The first and main one shows $\delta^{13} \mathrm{C}_{\mathrm{V} \text {-PDB }}$ values in the range of the Lower Eocene marine calcite from Veizer et al. [1999], which is in line with the marine nature of these deposits and the apparent absence of meteoric / continental alteration. The $\delta^{18} \mathrm{O}$ signatures are shifted toward negative values from 1 to $3 \%$, compared to the isotopic signatures of the Lower Eocene marine calcite from Veizer et al. [1999]. Such values may suggests the recrystallization of the foraminifera tests and a thermal fractionation of the oxygen isotopes associated to a gradual increase of temperature during burial. The preservation of the $\delta^{13} \mathrm{C}$ original signal could be explained by 
the fact that these sediments were indurated or compacted during early diagenesis and may represent relatively closed systems with respect to carbon isotopes [Molina et al., 2003].

The second field of values, is composed by samples taken below discontinuities S1 and S3. These boundaries are both marked by depleted $\delta^{13} \mathrm{C}_{\mathrm{V}-\mathrm{PDB}}$ signatures $(-1$ to $+0.5 \%$ ) compared 5 to marine calcite values $\left(+1.5\right.$ to $+2.5 \%$ ) and by a slight shift toward lower $\delta^{18} \mathrm{O}_{\mathrm{V}-\mathrm{PDB}}$ values. The $\delta^{13} \mathrm{C}_{\mathrm{V} \text {-PDB }}$ signatures are relatively high values to support precipitation or recrystallization from a meteoric fluid that are generally associated to a strongly negative carbon isotopic composition [Allan and Matthews, 1982; Quinn, 1991]. However, the $\delta^{13} \mathrm{C}_{\mathrm{V}-\mathrm{PDB}}$ signal of the abundant marine calcite in the sediments may have overprint signals from any meteoric carbonate that possibly precipitated in pores during early meteoric diagenesis associated to exposure [Dickson and Saller, 1995; Moore, 2001]. The recrystallization of foraminifera or a meteoric cement precipitation in the foraminifera chambers, mixed during sampling may explain such $\delta^{13} \mathrm{C}_{\mathrm{V} \text {-PDB }}$ values. The slight depletion of $\delta^{18} \mathrm{O}_{\mathrm{V}-\mathrm{PDB}}$ values observed below the surfaces is more difficult to interpret. Such a shift is often associated with the signal of isotopically light meteoric oxygen, but the $\delta^{18} \mathrm{O}_{\mathrm{V}-\mathrm{PDB}}$ seems hardly reliable (possible thermal fractionation during burial). This may be confirmed by the covariant trend (inverted J-shaped curve) between $\delta^{18} \mathrm{O}$ and $\delta^{13} \mathrm{C}$ values, which suggest progressive diagenesis under meteoric water conditions [Lohmann, 1988].

Finally, the last field of isotopic values is characterized by strongly negative values, both in $\delta^{18} \mathrm{O}_{\mathrm{V}-\mathrm{PDB}}$ and in $\delta^{13} \mathrm{C}_{\mathrm{V} \text {-PDB. }}$. These samples are located in the siliciclastic-dominated interval, where the carbonate fraction mainly corresponds to reworked Microcodium debris. Such values are common in biogenic calcrete dominated by such allochems [Kabanov et al., 2008; Brlek and Glumack, 2014]. They are interpreted to have formed in isotopic equilibrium with soil $\mathrm{CO} 2$, which derives mainly from root respiration and microbial decomposition of soil organic matter [Cerling, 1984; Brlek and Glumack, 2014]. The oxygen isotope composition of 
calcretes is also directly related to that of the meteoric (rainfall) water from which they formed, with some alteration caused by selective infiltration and evaporation (Alonso-Zarza, 2003). Such values points toward arid conditions with ephemeral heavy rainfall, characterizing the depositional period (Thanetian) of the Garumnian series [Schmitz and

5 Pujalte, 2003 and 2007]. These Garumnian deposits are eroded and reworked in deltaic facies during Ilerdian times.

\section{Insight from elemental geochemistry}

The multivariate statistical analysis (PCA and $\mathrm{ACH}$ ) carried out previously have enable to group samples that share comparable geochemical signatures. The PCA show strong positive correlations between $\mathrm{Al}_{2} \mathrm{O}_{3}$ with $\mathrm{Si}_{2} \mathrm{O}, \mathrm{TiO}_{2}, \mathrm{Na}_{2} \mathrm{O}$ and $\mathrm{K}_{2} \mathrm{O}$. These signatures are characteristic of siliciclastic-dominated samples. Indeed, these correlation are indicative of a terrigenous fraction mainly formed by quartz, clay minerals, calco-sodic- and K-feldspar, and disperse muscovite, which is in line with the petrographic observations. The co-variation between $\mathrm{SiO}_{2}$ and $\mathrm{Al}_{2} \mathrm{O}_{3}$, in particular, reflects the partition of $\mathrm{Si}$ between quartz and aluminosilicate minerals. Strong correlation between $\mathrm{Al}_{2} \mathrm{O}_{3}$ with $\mathrm{K}_{2} \mathrm{O}$ on the one hand, and $\mathrm{SiO}_{2}$ with $\mathrm{K}_{2} \mathrm{O}$ on the other hand confirm the presence of significant amounts of $\mathrm{K}$-feldspar in the terrigenous fraction [Lentz, 2003; Sageman and Lyons, 2003; Madhavaraju, 2015]. Similarly, the correlation between $\mathrm{Al}_{2} \mathrm{O}_{3}, \mathrm{SiO}_{2}$ and $\mathrm{TiO}_{2}$, probably highlights the presence of a heavy mineral contribution together with the siliciclastic input.

Negative correlations between $\mathrm{CaO}$ and these variables $\left(\mathrm{Al}_{2} \mathrm{O}_{3}, \mathrm{TiO}_{2}, \mathrm{Na}_{2} \mathrm{O}\right.$ and $\left.\mathrm{K}_{2} \mathrm{O}\right)$, obviously reflects the distribution of silicate-bound elements in the siliciclastic samples versus the Ca-rich carbonate samples. It is generally considered that $\mathrm{Ca}, \mathrm{Mg}, \mathrm{Sr}, \mathrm{Fe}$ and $\mathrm{Mn}$ contents are relevant to the interpretation of carbonate sedimentology and diagenesis [Graf, 1960; Morse, 2003]. The CAH realized on these carbonate-dominated samples enables to 
identify three main groups: samples taken in the vicinity of discontinuities S1 and S3; samples corresponding to basal lag deposits; other carbonate samples, without any peculiar stratigraphic distribution.

Samples located below discontinuities S1 and S3 are characterized by minimum contents in $5 \mathrm{MgO}, \mathrm{Fe}_{2} \mathrm{O}_{3}$ and $\mathrm{MnO}$. The decreasing values in $\mathrm{MgO}$ may indicate a dominant recrystallization of aragonitic or $\mathrm{HMC}$ allochems in a low-Mg calcite, that may have operate under oxidizing conditions as these calcites are also characterized by a minimum content in Fe and Mn [Webb et al., 2009; Tucker and Wright, 1992]. These geochemical data are consistent with an early meteoric diagenesis, associated to exposure [Moore, 2001]. The SrO content do not show such deviation in the vicinity of S1 and S3. The low SrO content observed in the first cycle, compared to the rest of the succession may eventually suggest partial leaching and/or recristallization due to meteoric diagenesis, associated with the discontinuity S1. However, the original low-magnesian calcite composition of these carbonates (calcite sea period; Hardie, 1996), originally low in SrO, may have also masked the depletion in SrO classically associated to meteoric diagenesis [Moore, 2001], thus explaining the absence of peculiar $\mathrm{Sr}$ signature below these surfaces. Finally, the large majority of the analyzed samples shows probably too low $\mathrm{Na}$ contents to show good correlation with $\mathrm{Ca}$ in the PCA. In the carbonate facies, Na could reflect the presence of fluid inclusions $(\mathrm{NaCl}$ type) in the calcite crystals or at grain boundaries, being electrically incompatible with the calcite lattice [Gasse et al., 1987].

A few samples shows anomalic values compared to the large majorities of the carbonate samples. Contents in $\mathrm{Al}_{2} \mathrm{O}_{3}, \mathrm{MgO}$ or $\mathrm{Fe}_{2} \mathrm{O}_{3}$ may display values five to ten times higher than the values of normal carbonates. In a lesser extent, $\mathrm{MnO}$ and $\mathrm{TiO}_{2}$ may also show minor shift toward higher values. These samples are rich in glauconite grains and glauconized Miliolid tests, which could explain such enrichments. The enrichments in $\mathrm{Fe}_{2} \mathrm{O}_{3}, \mathrm{MnO}$ and $\mathrm{TiO}_{2}$ may 
also be related to the abundance of soil-derived particles, such as oxides and hydroxides. The enrichment in $\mathrm{SrO}$ content of facies $\mathrm{C} 11(4567 \mathrm{ppm})$ may be due to the presence of reworked aragonitic allochems such as coral debris.

\section{$5 \quad$ Hierarchization of the stratigraphic surfaces}

In Serraduy, six major stratigraphic discontinuities (named S0 to S5) can be recognized in the studied interval. Their characterization and interpretation are difficult due to the apparent absence of erosional features or diagnostic elements of exposure. Indeed, no epikarst features, typical vadose diagenetic products or in situ Microcodium (a distinct and widespread feature in the whole Paleogene of the Pyrenees; Scheibner et al. [2007]) are observed. This observation can be generalized to other areas of the Graus-Tremp basin: on the Campo section, Payros et al. [2000] also conclude on the difficulty to identify stratigraphic sequences as none of the sequence bounding surfaces show evidence of subaerial exposure. However the approach developed in this study may help to characterize and hierarchize them.

The first surface (S0) corresponds to a major erosional surface, at the base of a $2 \mathrm{~m}$-thick, isopachous bed of polygenic and heterometric conglomerate ("Claret Conglomerate"). It was considered by Eichenseer and Luterbacher [1992] as a major incision (incised valley fill) and the basal sequence boundary of the so-called "Serraduy sequence" (Fig. 12). On the Campo section (reference section for the Ilerdian stage, situated $15 \mathrm{~km} \mathrm{W-NW}$ of Serraduy), it corresponds to a Microcodium-bearing surface, with karstic features [Payros et al., 2000; Scheibner et al., 2007]. Our geochemical dataset do not cover the base of the section. However, according to the latest isotopic studies by Schmitz and Pujalte [2003], the Surface S0 could correspond to the newly defined Paleocene/Eocene boundary and is considered as a major sequence boundary. 
Surfaces S1 and S3 show interesting similarities. In the Northern part of the area, S1 is a slightly erosive surface, with apparent conformity and selective dissolution. A moderate moldic porosity is observed below the discontinuity, resulting from the dissolution of aragonitic coral debris and gastropods. In the Southern part of the area, S1 corresponds to an 5 angular unconformity. S3 is a planar, very regular, mineralized surface (iron oxides and hydroxides and glauconite grains). A significant moldic porosity is also observed below the discontinuity, which suggests undersaturation of the diagenetic fluids with respect to aragonite, possibly meteoric fluids. The geochemical trends described above, both in terms of elemental and isotope geochemistry, are also indicative of such a meteoric diagenesis. The absence of any diagenetic or geochemical trend below S1 in section AB may be explained by an erosive character of the unconformity. S1 reflects exposure conditions, resulting of an eustatic drop combined with a significant tectonic activity (angular unconformity). Indeed, a significant syn-sedimentary tectonism during the deposition of the Alveolina Limestone Fm. is described in the form of a slow progressive flexuring of the basin floor due to the emplacement of a basal thrust sheet (referred in the regional nomenclature as Montsec thrust; Eichenseer and Luterbacher [1992]; Lopez-Blanco et al. [2003]). S3 also reflects subaerial exposure and is thus considered as a sequence boundary (Fig. 12). However, it only represents a low-amplitude sea-level drop (probably eustatic) without any significant tectonic. It is therefore less clearly expressed than S1, with no erosional feature or angular unconformity. The absence of sedimentary criteria of exposure may be explained by their erosion during exposure and the subsequent transgressive trend [Durlet and Loreau, 1996; Hamon et al., 2013]. More broadly, the global greenhouse context during the Paleogene period, may have led to short-term subaerial exposures, precluding the development and preservation of widespread vadose diagenetic products [Read, 1998; Pomoni-Papaioannou and Kostopoulou, 2010]. The subtropical but semi-arid to arid climate is also in agreement with a limited degree 
of meteoric alteration [Moore, 2001, Christ et al., 2012a]. Finally, it is important to note that most of the studied unit is composed of carbonates of original low-magnesian calcite composition (calcite sea period; Hardie, 1996), thus prone to limited leaching and dissolution by meteoric fluids during exposure.

5 At the scale of the studied area, S2 is an erosional surface (channel), whereas S4 is a glauconite-rich firmground. Surfaces S2 and S4 do not show any deviation of the isotopic curves as for S1 and S3. The isotopic analyses fall in the main field of values. Surface S2 is characterized by a sharp positive shift in most of the analyzed elements, which have been interpreted previously as representing a lag deposits, just above erosional surfaces. S4 lacks this peculiar geochemical trend and is characterized by values typical of silty carbonates. These two surfaces are not recognized by any author [Eichenseer and Luterbacher, 1992; Payros et al., 2000]. Regionally, these surfaces are not easily correlatable. The absence of marked diagenetic alteration and geochemical trends suggests that these surfaces are not linked to exposure events. As a consequence, we consider them as local surfaces, with a minor stratigraphic impact compared to S1 and S3 (Fig. 12).

Finally, in Serraduy, the last major discontinuity (surface S5) is a mineralized and glauconitic firmground, encrusted by Solenomeris and Bryozoans. For Eichenseer and Luterbacher [1992], it corresponds to a regional unconformity, bounding the Ager and Llimiana sequence (Fig. 12), and more generally, the Alveolina Limestone Fm. [Serra-Kiel et al., 1994]. On the Campo section, it consists in a sharp surface, between thinly stratified marly limestones and a mud-supported debris-flow, overlain by thin-bedded mixed siliciclastic-bioclastic turbidites [Payros et al., 2000; Scheibner et al., 2007]. This surface is interpreted as a maximumregression-related surface, resulting in sea-floor omission and lithification [Christ et al., $2012 b]$. 


\subsection{A new sequence stratigraphy model for the Alveolina Limestone Fm.}

Many sequence stratigraphic interpretations were already published for the studied stratigraphic interval in the present article. Some significant differences in both the number of sequences and the location of their bounding surfaces are easy to highlight between them

5 (Fig. 12). The first and main works providing a detailed facies architecture and sequence arrangement of the Alveolina Limestone Fm. at Serraduy are those by Eichenseer [1989] and Eichenseer and Luterbacher [1992], who also studied this complex unit across most of the Tremp-Graus region of the southern Pyrenees. These authors described two third-order sequences, for the studied interval: the Serraduy and Ager sequences. Based on the sedimentological and biostratigraphic analysis of the Campo section, Payros et al. [2000] defined a new sequence stratigraphic interpretation that integrates three third-order sequences for the same stratigraphic interval: IL-1, approximately corresponding to the Serraduy sequence sensu Eichenseer [1989]; IL-2 and IL-3 corresponding to the whole Ager sequence sensu Eichenseer [1989] (Fig. 12).

Based on the stacking pattern and on the identification of the major stratigraphic discontinuities, we recognized three depositional sequences, each composed of one or several small-scale cycles. The first depositional sequence is bounded by surfaces S0 and S1. It is composed of the first small-scale sequence and is similar to the "Serraduy sequence" [Eichenseer and Luterbacher, 1992] and the IL-1 sequence of Payros et al. [2000].

Considering the unconconformable character of the basal surface S0 and the prograding to aggrading geometry of the "Claret conglomerate" [Baceta et al., 2011; Schmitz and Pujalte, 2007], these first deposits may be considered as a lowstand system tract. The floodplain clay preservation and the development of paleosoils suggest an aggradation context, consistent with a transgressive system tract. The slightly erosive contact between these deposits and the first Alveolina and Orbitolites-rich limestone may be considered as a marine ravinement 
surface. Finally, the highstand deposits are absent or very limited in thickness, being eroded by the surface S1 (Fig. 12). The second and third depositional sequences are both composed of two small-scale cycles. The second depositional sequence is bounded by the surfaces S1 and S3 whereas the third one is limited by surfaces S3 and S5. They are equivalent to the unique Ager sequence of Eichenseer and Luterbacher [1992], but may correspond to the sequences IL-2 and IL-3 [Payros et al., 2000], in terms of boundary location but also in terms of facies succession. In this framework, the second depositional sequence may be divided in a lowstand system tract (southward-prograding siliciclastic-dominated interval between S1 and S2), transgressive and highstand system tracts dominated by carbonate facies (Fig. 12). The third depositional sequence does not record such lowstand system tract, as it is emplaced in a general context of increasing accommodation. A major flooding thus occurs directly after surface S3, which also corresponds to a transgressive surface with development of reefal facies (Fig. 12). Giving the local scale of this study, this new sequence stratigraphy model needs to be tested to a more regional scale, which will be addressed in future works.

\section{Conclusion}

The multi-scale description of the facies and the geometries, combined with a detailed geochemical study of the Alveolina Limestone Formation in the Serraduy area (North of the Graus-Tremp Basin) illustrated the complexity of these Early Ilerdian series.

Classically, based on the facies identification and the sedimentary architectures description, it was possible to identify high-resolution T/R cycles. However, the cycle-bounding discontinuities lack typical exposure sedimentary criteria (no epikarst features, typical vadose diagenetic products or in situ Microcodium), which prevent the hierarchization of the cyclebounding discontinuities and the recognition of larger-scale trends. This study demonstrated 
that a detailed isotopic and elemental geochemistry study may complete adequately the sedimentological characterization by providing geochemical signatures to cycle boundingdiscontinuities. In our case study, major discontinuities (angular unconformity, exposure surfaces) are characterized by a selective dissolution, a slight but sharp decrease in $\delta^{13} \mathrm{C}_{\mathrm{V}-\mathrm{PDB}}$

5 and in $\mathrm{Mg}, \mathrm{Fe}$ and $\mathrm{Sr}$ contents, below the surface. This hierarchization enables to recognize three depositional sequences, consistent with other recent regional studies. This study shows the pertinence of integrating sedimentological and geochemical studies, as a combined tool for sequence stratigraphy purposes.

Acknowledgements: The authors thank Pr. Michael Joachimsky at the University of Erlangen - Germany (Institute of Geology and Mineralogy), for performing the $\mathrm{C}$ and $\mathrm{O}$ stable isotopes analyses. The authors also thank Herman Ravelojaona (IFPEN) for thin sections preparation. The authors acknowledge the associate editor Pr. Pierre-Yves Collin and the reviewers Pr. Laurent Emmanuel and Dr. Philippe Léonide for their helpful comments that greatly improve this manuscript.

\section{References}

ALLAN J.R. \& MATTHEWS R.K. (1982). - Isotope signatures associated with early meteoric diagenesis. - Sedimentology, 29, 797-817.

ALONSO-ZARZA A.M. (2003). - Palaeoenvironmental significance of palustrine carbonates and calcretes in the geological record. - Earth-Science Reviews, 60, 261-298.

AZEVEDO D.A., TAMANQUEIRA J.B., DIAS J.C.M., CARMO A.P.B., LANDAU L. \&

GONCALVES F.T.T. (2008). Multivariate statistical analysis of diamondoid and biomarker data from Brazilian basin oil samples. - Fuel, 87, 2122-2130. 
BACETA J.I., PUJALTE V., WRIGHT V.P. \& SCHMITZ B. (2011). - Carbonate platform models, sea-level changes and extreme climatic events during the Paleocene-early Eocene greenhouse interval: a basin-platform-coastal plain transect across the southern Pyrenean basin. In: C. ARENAS, L. POMAR and F. COLOMBO, Eds, Geo-Guías 7. Pre-Meeting Field trips. - 28th IAS Meeting, 5 Zaragoza, 101-150.

BEAVINGTON-PENNEY S.J. \& RACEY A. (2004). - Ecology of extant nummulitids and other larger benthic foraminifera: applications in palaeoenvironmental analysis. - Earth-Science Reviews, 67, 219-265.

BOSELLINI F.R. \& PAPAZZONI C.A. (2003). - Palaeoecological significance of coral-encrusting foraminiferan associations: A case-study from the Upper Eocene of northern Italy. - Acta Palaeontologica Polonica, 48, 279-292.

BOUDAGHER-FADEL M.K. (2008). - Evolution and Geological Significance of Larger Benthic Foraminifera. - Developments in Palaeontology \& Stratigraphy, vol. 21. Elsevier Publisher, 540 p.

BRLEK M. \& GLUMAC B. (2014). - Stable isotopic $\left(\delta^{13} \mathrm{C}\right.$ and $\left.\delta^{18} \mathrm{O}\right)$ signatures of biogenic calcretes marking discontinuity surfaces: a case study from Upper Cretaceous carbonates of central Dalmatia and eastern Istria, Croatia. - Facies, 60, 3, 773-788.

BROCK J.C., PALASEANU-LOVEJOY M., WRIGHT C.W. \& NAYEGANDHI A. (2008). - Patchreef morphology as a proxy for Holocene sea-level variability, Northern Florida Keys, USA. - Coral Reefs, 27, 555-568.

BUTTERLIN J., VRIELYNCK B., BIGNOT G., CLERMONTE J., COLCHEN M., DERCOURT J., GUIRAUD R., POISSON A. \& RICOU L.E. (1993). - Lutetian (46-40 Ma). In: J. DERCOURT, L.E. RICOU and B. VRIELYNCK, Eds, Atlas of Tethys paleoenvironmental maps. - Paris, GauthiersVillars, 197-209. 
CARPENTER S.J. \& LOHMANN K.C. (1992). - Sr /Mg ratios of modern marine calcite: Empirical indicators of ocean chemistry and precipitation rate. - Geochimica et Cosmochimica Acta, 56, 1837 1849.

CERLING T.E. (1984). - The stable isotopic composition of modern soil carbonate and its relationship to climate. - Earth and Planetary Science Letters, 71, 229- 240.

CHOUKROUNE P., SEGURET M. \& GALDEANO A. (1973). - Caractéristique et évolution structurale des Pyrénées: un modèle de relation entre zone orogénique et mouvement des plaques. Bulletin de la Société Géologique de France, 15, 600-611.

CHRIST N., IMMENHAUSER A., AMOUR F., MUTTI M., PRESTON R., WHITAKER F.F., PETERHÄNSEL A., EGENHOFF S.O., DUNN P.A. \& AGAR S.M. (2012a). - Triassic Latemar cycle tops: Subaerial exposure of platform carbonates under tropical arid climate. - Sedimentary Geology, 265-266, 1-29.

CHRIST N., IMMENHAUSER A., AMOUR F., MUTTI M., TOMAS S, AGAR S.M., ALWAY R. \& KABIRI L. (2012b). - Characterization and interpretation of discontinuity surfaces in a Jurassic ramp setting (High Atlas, Morocco). - Sedimentology, 59, 1, 249-290.

CLARI P.A., DELLA PIERRE F. \& MARTIRE L. (1995). - Discontinuities in carbonate successions: identification, interpretation and classification of some Italian examples. - Sedimentary Geology, 100, $97-121$.

CRUMEYROLLE, P., LESUEUR, J.L., CLAUDE, D., et JOSEPH, P. (1992). - Architecture et faciès d'un prisme deltaïque de bas niveau marin : les Grès de Roda (Bassin Éocène Sud Pyrénéen). Livretguide de l'excursion ASF (Association des Sédimentologistes Français) du 25-27 Septembre 1992, Publication ASF $n^{\circ} 17,76$ p, http://www.sedimentologie.com/

CUEVAS-GOZALO M., DONSELAAR M.E. \& NIO S.D. (1985). - Eocene clastic tidal deposits in the Tremp-Graus Basin (Provs. of Lerida and Huesca). $-6^{\text {th }}$ European Regional Meeting IAS, Lerida, Guidebook Excursion n6, 215-266. 
DICKSON J.A.D. (1966). - Carbonate identification and genesis as revealed by staining. - Journal of Sedimentary Research, 36, 2, 491-505.

DICKSON J.A.D. \& SALLER A.H. (1995). - Identification of subaerial exposure surfaces and porosity preservation in Pennsylvanian and Lower Permian shelf limestones, eastern Central basin platform, Texas. In : D.A. BUDD, A.H. SALLER and P.M. HARRIS, Eds, Unconformities and porosity in carbonate strata. - AAPG Mem., 63, 239-258.

DURLET C. \& LOREAU J.P. (1996). - Séquence diagénétique intrinsèque des surfaces durcies: mise en évidence de surface d'émersion et de leur ablation marine. Exemple de la plate-forme bourguignonne, Bajocien (France). - C. R. Acad. Sci., Paris, 323, 389-396.

EICHENSEER H. (1988). - Facies Geology of Late Maestrichtian to Early Eocene coastal and shallow marine sediments (Tremp-Graus Basin, Northeastern Spain). - Ph.D. Thesis, Univ. Tübingen, Germany, 237 p.

EICHENSEER H. \& LUTERBACHER H. (1992). - The Marine Paleogene of the Tremp Region (NE Spain) - Depositional Sequences, Facies History, Biostratigraphy and Controlling Factors. - Facies, 27, 119-152.

EMBRY, A.F. (1993). - Transgressive-regressive (T-R) sequence analysis of the Jurassic succession of the Sverdrup Basin, Canadian Artic Archipelago. Canadian Journal of Earth Sciences, 30, 301-320.

EMERY D. \& MYERS K.J. (1996). - Sequence Stratigraphy. - Blackwell Science Ltd, 297 p.

FONNESU F. (1984). - Estratigrafia fisica y analisis de facies de la secuenca de Figols entre el Rio Noguera Pallaresa e Iscles (Prov. de Lerida y Huesca). - Ph.D. Thesis, Fac. Ciences Univ. Auton. Barcelona, Spain, 317 p.

FRIEDRICH O., SCHMIEDL G., ERLENKEUSER H. (2006). - Stable isotope composition of Late Cretaceous benthic foraminifera from the southern South Atlantic: Biological and environmental effects. - Marine Micropaleontology, 58, 135- 157. 
GARRIDO-MEGIAS A. \& RIOS L.M. (1972). - Sintesis geologica del Secundario y Terciario entre los rios Cinca y Segre (Pirineo Central de la vertiente surpirenaica, provincias de Huesca y Lerida). Bol. Geol. Min., LXXXIII, 1-47.

\section{GASSE F., FONTES J.C., PLAZIAT J.C., CARBONEL P., KACZMARSKA I., DE DECKKER P.,}

SOULIE-MARSCHE I., CALLOT I. \& DUPEUBLE P.A. (1987). - Biological remains, geochemistry and stable isotopes for the reconstruction of environmental and hydrological changes in the Holocene lakes from North Sahara. - Palaeogeogr. Palaeoclimatol. Palaeoecol., 60, 1 - 46.

GEEL T. (2000). - Recognition of stratigraphic sequences in carbonate platform and slope deposits: empirical models based on microfacies analysis of Paleogene deposits in Southeastern Spain. Palaeogeography, Palaeoclimatology, Palaeoecology, 155, 211-238.

GRADSTEIN F.M., OGG J.G. \& SMITH A.G. (2004). - A geologic time scale. - Cambridge University Press, Cambridge, UK, 610 p.

GRAF D. L. (1960). Geochemistry of carbonate sediments and sedimentary carbonate rocks. Part I : Carbonate Mineralogy, Carbonate Sediments. - Illinois State Geological Survey, 39 p.

HAMON Y., SANTERRE Y., GRANJEON D., CONESA G. \& BORGOMANO J. (2013). - Early diagenesis in meteoric versus brackish environments: Example of the Late Oligocene-Early Miocene, littoral, mixed sedimentary succession of Carry-Le-Rouet (southeastern France). - Bull. Soc. géol. France, 184, 6, 601-620.

HARDIE L.A. (1996). - Secular variation in seawater chemistry: An explanation for the coupled secular variation in the mineralogies of marine limestones and potash evaporites over the past 600 m.y. - Geology, 24, 279-283.

HAY W.W., DECONTO R., WOLD C.N., WILSON K.M., VOIGT S., SCHULZ M., WOLDROSSBY A., DULLO W.C., RONOV A.B., BALUKHOVSKY A.N. \& SOEDING E. (1999). Alternative Global Cretaceous Paleogeography. In: E. BARRERA and C. JOHNSON, Eds, The 
HILLGARTNER H. (1998). - Discontinuity surfaces on a shallow-marine carbonate platform. Journal of Sedimentary Research, 68, 1093-1108.

HOTTINGER L. (1960). - Recherches sur les Alvéolines du Paléocène et de l'Eocène. - Mem. Suisses Paleont., 75-76, $243 \mathrm{p}$

HOTTINGER L. (1997). - Shallow benthic foraminiferal assemblages as signals for depth of their deposition and their limitations. - Bulletin de la Société Géologique de France, 168, 491-505.

IMMENHAUSER A., SCHLAGER W., BURNS S.J., SCOTT R.W., GEEL T., LEHMANN J., VAN DER GAAST S. \& BOLDER-SCHRIJVER L.J.A. (2000). - Origin and correlation of disconformity surfaces and marker beds, Nahr Umr Formation, Northern Oman. In: A.S. ALSHARHAN and R.W. SCOTT, Eds., Middle East Models of Jurassic/Cretaceous Carbonate Systems. - SEPM Special Publication, 69, 209-225.

JOACHIMSKI M.M. (1994). - Subaerial exposure and deposition of shallowing upward sequences: evidence from stable isotopes of Purbeckian peritidal carbonates (basal Cretaceous), Swiss and French Jura Mountains. - Sedimentology, 41, 805-824.

KABANOV P., ANADÓN P. \& KRUMBEIN W.E. (2008). - Microcodium: An extensive review and a proposed non-rhizogenic biologically induced origin for its formation. - Sedimentary Geology, 205, 79-99.

KAUFMAN L. \& ROUSSEEUW P.J. (1990). - Finding Groups in Data: An Introduction to Cluster Analysis. - Wiley Series in Probability and Statistics, Wiley, New York, 368 p.

KOSIR A. (2004). - Microcodium revisited: root calcification products of terrestrial plants on carbonate-rich substrates. - Journal of Sedimentary Research, 74, 6, 845-857.

KRUMBEIN W.E. \& JENS K. (1981). - Biogenic rock varnishes of the Negev Desert (Israel): an ecological study of Iron and Manganese transformation by cyanobacteria and fungi. - Oecologia, 50, 25-38. 
LENTZ D. R. (2003). - Geochemistry of Sediments and Sedimentary Rocks: Evolutionary

Considerations to Mineral Deposit-Forming Environments. - Geological Association of Canada, 184p.

LETURCQ T. (1999). - Dynamique récifale à l’Ilerdien : exemple du bassin de Graus-Tremp (Pyrénées, Espagne). - Ph.D. Thesis, Université Paris VI, France, 376 p.

5 LOHMANN K. C. (1988). - Geochemical patterns of meteoric diagenetic systems and their application to studies of paleokarst. In: JAMES N.P. \& CHOQUETTE P.W., Eds., Paleokarst. Springer-Verlag New-York, 58-80.

LOPEZ-BLANCO M., MARZO M. \& MUÑOZ J.A. (2003). - Low-amplitude, synsedimentary folding of a deltaic complex: Roda Sandstone (lower Eocene), South-Pyrenean Foreland Basin. Basin Research, 15, 73-95.

LUKASIK J. \& JAMES N.P. (2003). - Deepening-upward subtidal cycles, Murray Basin, South Australia. - Journal of Sedimentary Research, 73, 653-671.

LUTERBACHER H.P., EICHENSEER H., BETZLER CH. \& VAN DEN HURK A.M. (1991). Carbonate-siliciclastic depositional systems in the Paleogene of the South Pyrenean foreland basin: a sequence-stratigraphic approach. - Spec. Publ. Int. Ass. Sediment., 12, 391-407.

MADHAVARAJU J. (2015). Geochemistry of late cretaceous sedimentary rocks of the Cauvery Basin, South India: Constraints on paleoweathering, provenance, and end Cretaceous environments. In: M. RAMKUMAR, Ed., Chemostratigraphy: Concepts, Techniques, and Applications. - Elsevier Publisher, 185-214. G.S., DE ALBUQUERQUE MEDEIROS LIMA E. \& DO AMARAL VAZ MANSO V. (2008). Principal component analysis (PCA) and mineral associations of litoraneous facies of continental shelf carbonates from northeastern Brazil. - Continental Shelf Research, 28, 2709-2717. 
MATEU-VICENS G., POMAR L. \& FERRANDEZ-CANADELL C. (2012). - Nummulitic banks in the upper Lutetian 'Buil level', Ainsa Basin, South Central Pyrenean Zone: the impact of internal waves. - Sedimentology, 59, 527-552.

MEY P.W.H., NAGTEGAAL P.J.C., ROBERTI K.J. \& HARTEVELT J.J.A. (1968). -

5 Lithostratigraphic subdivision of posthercynian deposits in the South-Central Pyrenees, Spain. - Leidse Geol. Meded., 41, 221-228.

MIDDLETON G.V. (1991). - A short historical review of clastic tidal sedimentology. In: D.G. SMITH, G.E. REINSON, B.A. ZAITLIN and R.A. RAHMANI, Eds, Clastic Tidal Sedimentology. Canadian Society of Petroleum Geology Memoir, 16, Calgary, Canada, ix-xv.

MOLINA E., ANGORI E., ARENILLAS I., BRINKHUIS H., CROUCH E.M., LUTERBACHER H., MONECHI S. \& SCHMITZ B. (2003). - Correlation between the Paleocene/Eocene boundary and the Ilerdian at Campo, Spain. - Revue de micropaleontology, 46, 95-109.

MOORE C.H. (2001). - Carbonate Reservoirs. Porosity Evolution and Diagenesis in a sequence Stratigraphic Framework. - Developments in Sedimentology, 55, Elsevier Science Ldt., Amsterdam (Nederland), $460 \mathrm{p}$.

MORSE J. W. (2003). Formation and Diagenesis of Carbonate Sediments. In: F. T. MACKENZIE, Ed., Sediments, Diagenesis, and Sedimentary Rocks. Treatise on Geochemistry, Volume 7. - Elsevier Publisher, 67-85.

MORSILLI M., BOSELLINI F.R., POMAR L., HALLOCK P., AURELL M. \& PAPAZZONI C.A. (2012). - Mesophotic coral buildups in a prodelta setting (Late Eocene, southern Pyrenees, Spain): a mixed carbonate-siliciclastic system. - Sedimentology, 59, 766-794.

MUNOZ J.A. (1992). - Evolution of a continental collision belt: ECORS-Pyrenees crustal balanced cross-section. In: K. R. McCLAY, Ed., Thrust Tectonics. Springer Netherlands, 235-246. 
MUTTI E., SEGURET M. \& SGAVETTI M. (1988). - Sedimentation and Deformation in the Tertiary Sequences of the Southern Pyrenees. - Guide Book of Field Trip 7, AAPG Mediterranean Basins Conference, Nice, France, Special Publication of the Institute of Geology of the University of Parma, $157 \mathrm{p}$.

5 NIJMAN W. \& NIO S.D. (1975). - The Eocene Montañana delta. In: J. ROSELL and C. PUIGDEFABREGAS, Eds, Sedimentary evolution of the Paleogene South Pyrenean Basin. - $9^{\text {th }}$ International Congress I.A.S., Nice, part B, 56 p.

OLARIU C., STEEL J., DALRYMPLE R.W. \& GINGRAS K. (2012). - Tidal dunes versus tidal bars: The sedimentological and architectural characteristics of compound dunes in a tidal seaway, the lower Baronia Sandstone (Lower Eocene), Ager Basin, Spain. - Sedimentary Geology, 279, 134-155.

ORI G. \& FRIEND P. (1984). - Sedimentary basins formed and carried piggyback on active thrust sheets. - Geology, 12, 475-478.

PAYROS A., PUJALTE V., BACETA J.I., BERNAOLA G., ORUE-ETXEBARRIA X., APPELANIZ E., CABALLERO F. \& FERRANDEZ C. (2000). - Lithostratigraphy and sequence stratigraphy of the Upper Thanetian to Middle Ilerdian Strata of the Campo Section (Southern Pyrenees, Spain): Revision and new data. - Rev. Soc. Geol. España, 13, 2, 213-226.

PERRIN C. (1992). - Signification écologique des Foraminifères Acervulinidés et leur rôle dans la formation de faciès récifaux et organogènes depuis le Paléocène. - Geobios, 25, 725-751.

PLAZIAT J.C. (1975). - L'Ilerdien à l'intérieur du Paléogène languedocien; ses relations avec le Sparnacien, l'Ilerdien sud-Pyrénéen, l'Yprésien et le Paléocène. - Bulletin de la Société géologique de France, XVII, 168-181.

PLAZIAT J.C. (1984). - Le domaine pyrénéen de la fin du Crétacé à la fin de l’Eocène. Stratigraphie, paléo-environnements et évolution paléogéographique. Ph.D. Thesis, Université Paris-Sud, France, $1362 \mathrm{p}$. 
PLAZIAT J.C. \& PERRIN C. (1991). - Multikilometer-sized reefs built by Foraminifera

(Solenomeris) from the early Eocene of the Pyrenean domain (S. France, N. Spain) : Palaeoecologic relations with coral reefs. - Palaeogeography, Palaeoclimatology, Palaeoecology, 96, 195-223.

POMAR L. (2001). - Types of carbonate platforms: a genetic approach. - Basin Research, 13, 313334.

POMAR L., MATEU-VICENS G., MORSILLI M. \& BRANDANO M. (2014). - Carbonate ramp evolution during the Late Oligocene (Chattian), Salento Peninsula, southern Italy. Palaeogeography, Palaeoclimatology, Palaeoecology, 404, 109-132.

POMONI-PAPAIOANNOU F.A. \& KOSTOPOULOU V. (2010). - Subaerial exposure-related discontinuities in shallow-water platform carbonate successions (Late Triassic-Pelagonian \& Early Jurassic-Gavrovo Tripolitza, Greece). - Hellenic Journal of Geosciencies, 45, 227-238.

PUJALTE V., BACETA J.I., SCHMITZ B., ORUE-ETXEBARRIA X., PAYROS A., BERNAOLA G., APELLANIZ E., CABALLERO F., ROBADOR A., SERRA-KIEL J. \& TOSQUELLA J. (2009). - Redefinition of the Ilerdian Stage (early Eocene). - Geologica Acta, 7, 1-2, 177-194.

PURSER B.H. (1980). - Sédimentation et diagenèse des carbonates néritiques récents (Tome 1). Société des Editions Technip, Paris, France, 388 p.

QUINN T.M. (1991). - Meteoric diagenesis of Plio-Pleistocene limestones at Enewetak Atoll. - J. Sediment. Res., 61, 5, 681-703.

RASSER M.W., SCHEIBNER C. \& MUTTI M. (2005). - A paleoenvironmental standard section for Early Ilerdian tropical carbonate factories (Corbières, France; Pyrenees, Spain). - Facies, 51, 217-232.

READ J.F. (1998). - Phanerozoic carbonate ramps from greenhouse, transitional and ice-house worlds: clues from field and modelling studies. - Geological Society of London Special Publications, 149, $107-$ 135. 
READING H.G. (1996). - Sedimentary Environments: Process, Facies and Stratigraphy - Third Edition. - Blackwell Science, 688 p.

REMACHA E. \& ZAMORANO M. (1989). - Reflejo de la estratigrafía secuencial del Eoceno inferior surpirenaico en una parte de la sección de Campo. - Geogaceta, 6, 94-96.

5 REY J. \& BOUSQUET J.-P. (1981). - Observations préliminaires sur les paléoenvironnements de l'Ilerdien de Coustouge (Corbières, France). - Geobios, 14, 5, 655-659.

RODUIT N. (2008). - JMicroVision: image analysis toolbox for measuring and quantifying components of high-definition images. - http://www.jmicrovision.com/index.htm.

ROURE F., CHOUCROUNE P., BERASTEGUI X., MUNOZ J.A., VILLIEN A., MATHERON P., BAREYT M., SÉGURET M., CAMARA P. \& DERAMOND J. (1989). - Ecors deep seismic data and balanced cross-section: geometric constrains on the evolution of the Pyrenees. - Tectonics, 8, 41-50.

SAGEMAN B. B. \& LYONS T. W. (2003). - Geochemistry of Fine-grained Sediments and Sedimentary Rocks. In: F. T. MACKENZIE, Ed., Sediments, Diagenesis, and Sedimentary Rocks. Treatise on Geochemistry, Volume 7. - Elsevier Publisher, 115-158.

SATTLER U., IMMENHAUSER A., HILLGÄRTNER H. \& ESTEBAN M. (2005). -

Characterization, lateral variability and lateral extent of discontinuity surfaces on a carbonate platform (Barremian to Lower Aptian, Oman). - Sedimentology, 52, 339-361.

SCHEIBNER C., RASSER M.W. \& MUTTI M. (2007). - The Campo Section (Pyrenees, Spain) revisited: Implications for changing benthic carbonate assemblages across the Paleocene-Eocene boundary. - Palaeogeography, Palaeoclimatology, Palaeoecology, 248, 145-168.

SCHEIBNER C. \& SPEIJER R.P. (2008). - Late Paleocene-early Eocene Tethyan carbonate platform evolution - A response to long- and short-term paleoclimatic change. - Earth-Science Reviews, 90, 71102. 
SCHLAGER W. (2005). - Carbonate Sedimentology and Sequence Stratigraphy. - SEPM Concepts in Sedimentology and Paleontology Series, 8, 200 p.

SCHMIEDL G., PFEILSTICKER M., HEMLEBEN C., MACKENSEN A. (2004). - Environmental and biological effects on the stable isotope composition of recent deep-sea benthic foraminifera from

5 the western Mediterranean Sea. - Marine Micropaleontology, 51, 129- 152.

SCHMITZ B., ASARO F., MOLINA E., MONECHI S., VON SALIS K. \& SPEIJER R.P. (1997). -

High-resolution iridium, $\delta^{13} \mathrm{C}, \delta^{18} \mathrm{O}$, foraminifera and nannofossil profiles across the latest Paleocene benthic extinction event at Zumaya, Spain. - Palaeogeography, Palaeoclimatology, Palaeoecology, 133, 49-68.

SCHMITZ B. \& PUJALTE V. (2003). - Sea-level, humidity, and land-erosion records across the initial Eocene thermal maximum from a continental-marine transect in northern Spain. - Geology, 31, $689-692$.

SCHMITZ B. \& PUJALTE V. (2007). - Abrupt increase in seasonal extreme precipitation at the Paleocene-Eocene boundary. - Geology, 35, 215-218.

SCHOLLE P.A., BEBOUT D.G. \& MOORE C.H. (1983). - Carbonate depositional environments. AAPG Memoir 33, AAPG, Tulsa, Oklahoma, 708 p.

SEGURET M. (1972). - Étude tectonique des nappes et séries décollées de la partie centrale du versant sud des Pyrénées - caractère synsédimentaire, rôle de la compression et de la gravité. - Série géologie structurale 2, Publications de l'Université des Sciences et Techniques du Languedoc (USTELA), Montpellier, France, 155 p.

SERRA-KIEL J., CANUDO J.I., DINARES J., MOLINA E., ORTIZ N., PASCUAL J.O., SAMSO J.M. \& TOSQUELLA J. (1994). - Chronostratigraffía de los sedimentos marinos del Terciario inferior de la Cuenca de Graus-Tremp (Zona Central Surpirenaica). - Rev. Soc. Geol. Espańa, 7, 3-4, 273-297. 
SHERMAN C.E., FLETCHER C.H. \& RUBIN K.H. (1999). Marine and meteoric diagenesis of Pleistocene carbonates from a nearshore submarine terrace, Oahu, Hawaii. - Journal of Sedimentary Research, 69 (5), 1083-1097.

SLOAN L.C. \& THOMAS E. (1998). - Global climate of the late Paleocene epoch: modeling the 5 circumstances associated with a climatic "event". In: M.P. AUBRY, S. LUCAS, W.A. BERGGREN, Eds, Late Paleocene-early Eocene climatic and biotic events in the marine and terrestrial records. Columbia University Press, New York, 138-157.

STRASSER A. \& HILLGÄRTNER H. (1998). - High-frequency sea-level fluctuations recored on a shallow carbonate platform (Berriasian and Lower Valanginian of Mount Salève, French Jura). Eclogae Geologicae Helvetiae, 91, 375-390.

TOSQUELLA J. (1988). - Estudi sedimentològic i biostratigràfic de la Formació Gresos de Roda (Eocè, Conca de Tremp-Graus). - Tesis Licenciatura, Univ. Barcelona, Spain, 540 p.

TUCKER M.E. \& WRIGHT V.P. (1992). - Carbonate Sedimentology. - Blackwell scientific publications, Oxford, UK, 482 p.

VEIZER J., ALA D., AZMY K., BRUCKSCHEN P., BUHL D., BRUHN F., CARDEN G.A.F., DIENER A., EBNETH S., GODDERIS Y., JASPER T., KORTE C., PAWELLEK F., PODLAHA O.G. \& STRAUSS H. (1999). ${ }^{87} \mathrm{Sr} /{ }^{86} \mathrm{Sr}, \delta^{13} \mathrm{C}$ and $\delta^{18} \mathrm{O}$ evolution of Phanerozoic seawater. Chemical Geology, 161, 59-88.

VINCENT S.J. (2001). - The Sis palaeovalley: a record of proximal fluvial sedimentation and drainage basin development in response to Pyrenean mountain building. - Sedimentology, 48, 12351276.

WACHTER E. \& HAYES J.M. (1985). - Exchange of oxygen isotopes in carbon-dioxide-phosphoric acid systems. - Chemical Geology, 52, 365-374. 
WALKER R.G. (1992). - Facies, facies models and modern stratigraphic concepts. In: R.G. Walker, and N.P. James, Eds, Facies Models, Response to Sea Level Change. - Geological Association of Canada, St. John's, Newfoundland, 1-14.

WEBB G.E., NOTHDURFT L.D., KAMBER B.S., KLOPROGGE J.T. \& ZHAO J.-X. (2009). - Rare

5 earth element geochemistry of scleractinian coral skeleton during meteoric diagenesis: a sequence through neomorphism of aragonite to calcite. - Sedimentology, 56(5), 1433-1463.

WILSON J.L. (1975). - Carbonate facies in Geologic History. - Springer-Verlag, Berlin-HeidelbergNew York, 471 p.

WOLD S., ESBENSEN K. \& GELADI P. (1987). - Principal component analysis. - Chemom. Intell. Lab. Syst., 2, 37-52.

WOOD R. (1999). - Reef evolution. - Oxford University Press, Oxford, 426 p.

WOODY D.T., SMITH J.J., KRAUS M.J. \& HASIOTIS S.T. (2014). - Manganese-bearing rhizoconcretions in the Willwood Formation, Wyoming, USA: Implications for paleoclimate during the Paleocene-Eocene thermal maximum. - Palaios, 29(6), 266-276. aberrations in global climate 65 Ma to present. - Science, 292, 686-693.

\section{Figure captions}

Figure 1: A) Geological map of the south-central Pyrenees (modified from Vincent [2001]) and location of the study area (Serraduy). B) Geological map showing the main lithostratigraphic formations of Early Eocene age in the Rigaborzana area (modified from Mapa Geologic de Catalunya 1:250000). C) Geological map showing the main lithostratigraphic formations of Early Eocene age in the Serraduy area, with location of the 
sedimentary sections described in this study and correlation plate of Fig. 5 in red (UTM coordinates, WGS84) (modified from Mapa Geologic de Catalunya 1:250000).

Figure 2: General stratigraphy (names of formations are informal), main lithologies and depositional environments of the Early Eocene series of the Graus-Tremp Basin. Paleogene zonations of larger foraminifera (Gradstein et al., 2004 and Serra-Kiel et al., 1994).

Figure 3: A) Field photograph showing facies A1, heterometric and heterolithic conglomerate. B) Field photograph showing facies B2, interstratified with B1. C) Field photography showing prograding sets of the B1 facies forming a lobe structure. D) General view of the main cliff studied in the Serraduy area (geobodies and bounding surfaces are underlined). E) General view of the deltaic complex in the Serraduy area (underlined bodies). The deltaic lobes show compensations cycles and are largely incised at their top by a deeplyscoured channel filled by a tidal megadune (facies C4). F) Field photography showing one of the build-ups that developed over the surface S3 (central part of the outcrops) and corresponding line drawing and facies interpretation. G) Field photography showing another build-up (South Serraduy) that developed over the surface S3, overlain by facies D1, E1 and E2. H) Field photography showing the geometry of the build-up observed in the Northern part of the Serraduy area, developed during the first small-scale cycle.

Figure 4: A) Transmitted light plane-polarized (PPL) photomicrograph showing facies B1 (dominated by quartz and Microcodium fragments) and small Miliolids (white arrow). B) PPL photomicrograph showing facies B1, dominated by quartz and Microcodium fragments (white arrow). C) PPL photomicrograph showing facies B3, a bioclastic sandy limestone. Presence of green algae (black arrows), serpulids, gastropods, Miliolids (white arrow). D) PPL photomicrograph showing facies B4, dominated by gastropods (black arrows) and Orbitolite fragments (white arrows) in a silty mudstone matrix. E) Transmitted light crossed-polarized (XPL) photomicrograph of facies $\mathrm{C} 1$ composed of a wackestone-packstone dominated by 
Alveolina (white arrows), Orbitolites (black arrows) and Miliolids (grey arrows). F) PPL photomicrograph of C3 (micro-grainstone dominated by Miliolids, intraclasts and echinoids debris). G) PPL photomicrographs showing the facies C4, that fills the incision in Serraduy (micrograinstone with intraclasts and miliolids). H) PPL photomicrograph showing facies D1

5 (Alveolina (white arrows)-Nummulites (black arrows) wackestone). I) PPL photomicrograph showing Operculina-dominated wackestone (facies D2). In this example, Operculina (white arrows) are associated to pelecypod and echinoid debris. J) PPL photomicrograph showing facies E1 (Assilina (black arrows)-dominated wackestone, Operculina (white arrows)). K) PPL photomicrograph showing facies F2 composed of coral (black arrow) encrusted by red algae (white arrow). L) PPL photomicrograph showing facies F3 dominated by the red algaeSolenomeris association (white arrows).

Figure 5: 3D-Model illustrating the general architecture of the Ilerdian Alveolina Limestone Fm. in the Serraduy area (location on Fig. 1). Facies and boundaries of the small-scale cycles (bold lines, named as S0 to S5) and associated architectures are highlighted. The location of the different field photographies of Fig. 3 are specified.

Figure 6: A) Conceptual depositional model for the Ilerdian Alveolina Limestone Fm. in the Serraduy area, and distribution of the main sedimentary facies. B) Sequence stratigraphy framework of the series, showing the identification of five small-scale cycles.

Figure 7: Cross-plot of $\delta^{13} \mathrm{C}_{\mathrm{V}-\mathrm{PDB}}$ versus $\delta^{18} \mathrm{O}_{\mathrm{V}-\mathrm{PDB}}$ values for three sections: $\mathrm{AB}$ (diamond), $\mathrm{H}$ (triangles) and $\mathrm{N}$ (circles). Samples with white symbols correspond to Alveolina, gray symbols correspond to Nummulites, and black symbols correspond to bulk, dominated by Microcodium debris.

Figure 8: Results of $\delta^{13} \mathrm{C}_{\mathrm{V}-\mathrm{PDB}}$ and $\delta^{18} \mathrm{O}_{\mathrm{V}-\mathrm{PDB}}$ analysis, plotted vertically along the three studied sections $\mathrm{AB}, \mathrm{H}$ and $\mathrm{N}$. The different cycles and their bounding discontinuities (S0 to 
S5) are also mentioned. Samples with white circles correspond to Alveolina, gray circles correspond to Nummulites, and black circles correspond to bulk, dominated by Microcodium debris.

Figure 9: A) PCA projection of the variables studied (without $\mathrm{SiO}$ ) on the principal axes 1 and 2 (left) and axes 1 and 3 (right). Principal components 1 and 2 represent $70.52 \%$ of the total variability (53.36\% and $17.15 \%$ respectively) whereas the projections on axes 1 and 3 represent $64.31 \%$ of the total variability $(53.36 \%$ and $10.94 \%$ respectively). B) Biplots corresponding to a representation of the analysed samples in the PCA space presented in Fig. 9A. Siliciclastic-dominated, carbonate-dominated samples are respectively highlighted in green and blue. Samples located below discontinuities S1 and S3 are shown in red. Scattered values ouside of these domains correspond to lag deposits. C) PCA projection of the variables studied (elemental geochemistry subset including $\mathrm{SiO}$ analysis) on the principal axes 1 and 2 (left) and axes 1 and 3 (right). Principal components 1 and 2 represent $76.17 \%$ of the total variability $(64.66 \%$ and $11.51 \%$ respectively) whereas the projections on axes 1 and 3 represent $75.40 \%$ of the total variability ( $64.66 \%$ and $10.74 \%$ respectively).

Figure 10: Results of major ( $\mathrm{Mg}$ in \%), minor ( $\mathrm{Al}, \mathrm{Fe}, \mathrm{K}$ in \%) and trace elements $(\mathrm{Mn}, \mathrm{Ti}$, $\mathrm{Sr}, \mathrm{Na}$ in $\mathrm{ppm}$ ), plotted vertically along the two studied sections $\mathrm{AB}$ and $\mathrm{N}$. The different sedimentary discontinuities (S0 to S5) are also mentioned.

Figure 11: Dendrogram resulting from the AHC performed on the carbonate-dominated samples of the dataset. All the observations are grouped into three main categories. The dotted line represents the automatic truncation. Sample C11 is an atypical value.

Figure 12: Sequence stratigraphy for the Serraduy area with proximal to distal evolution of the systems tracts. 
Table 1: Isotopic and elemental geochemistry analyses realized on the three studied sections $\mathrm{AB}, \mathrm{N}$ and $\mathrm{H}$.

Table 2: A) PCA correlation matrix showing correlation coefficient calculated with the elemental geochemistry dataset (without $\mathrm{SiO}$ ). B) PCA correlation matrix showing correlation 5 coefficient calculated with the elemental geochemistry subset including $\mathrm{SiO}$ analysis. 


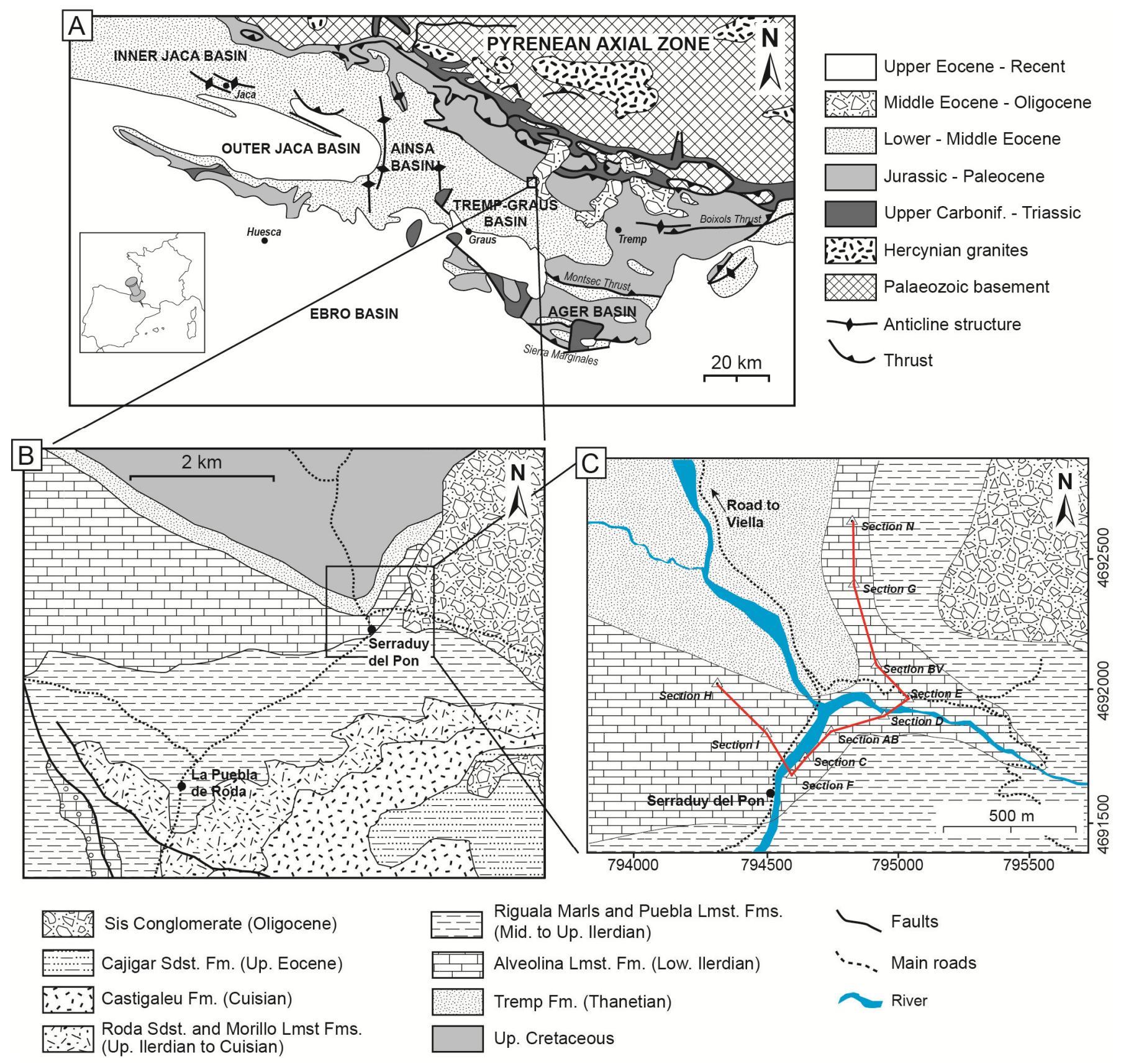

Figure 1 


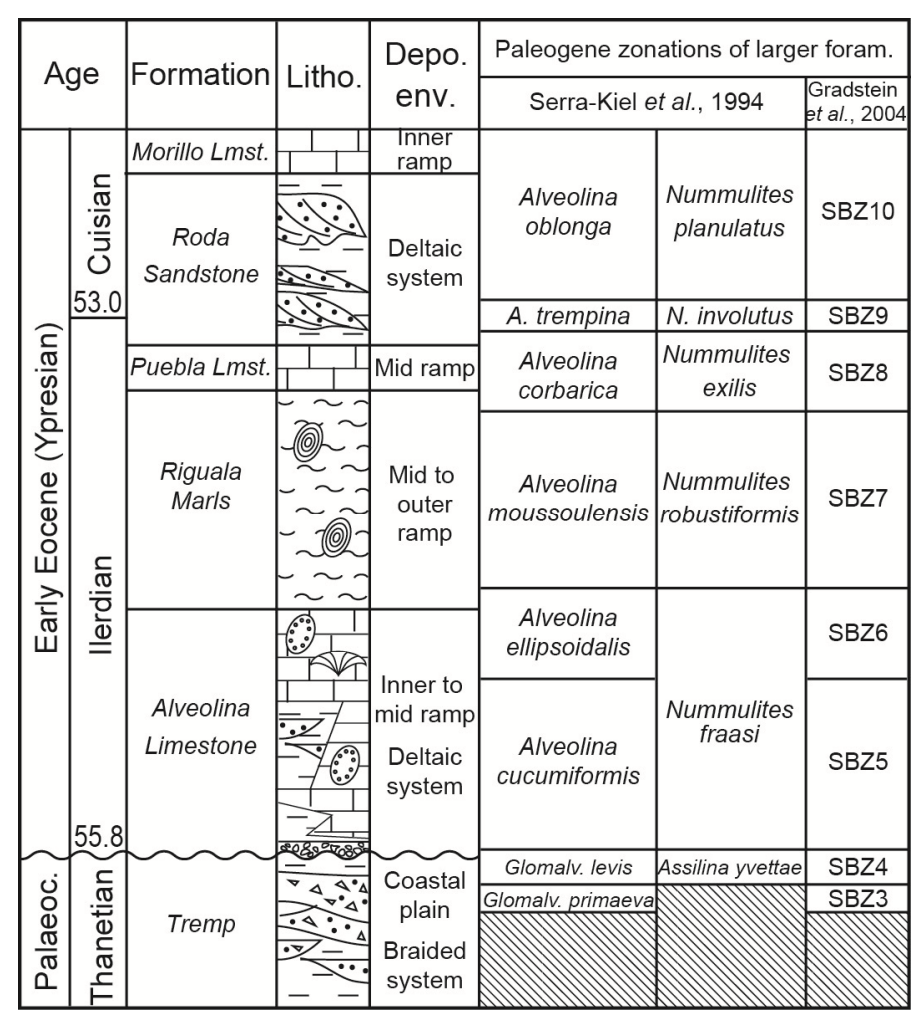

Figure 2 

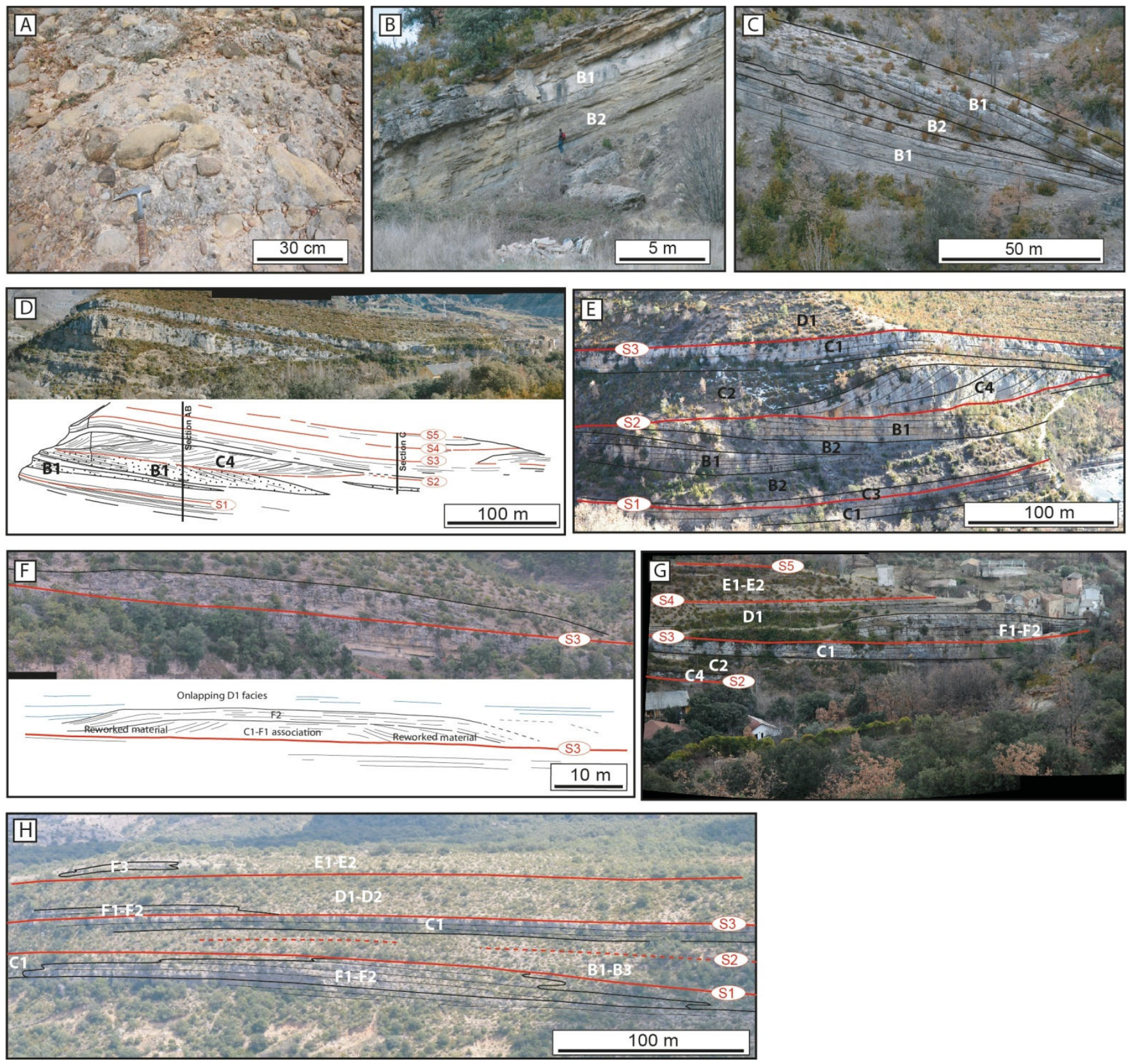

Figure 3 

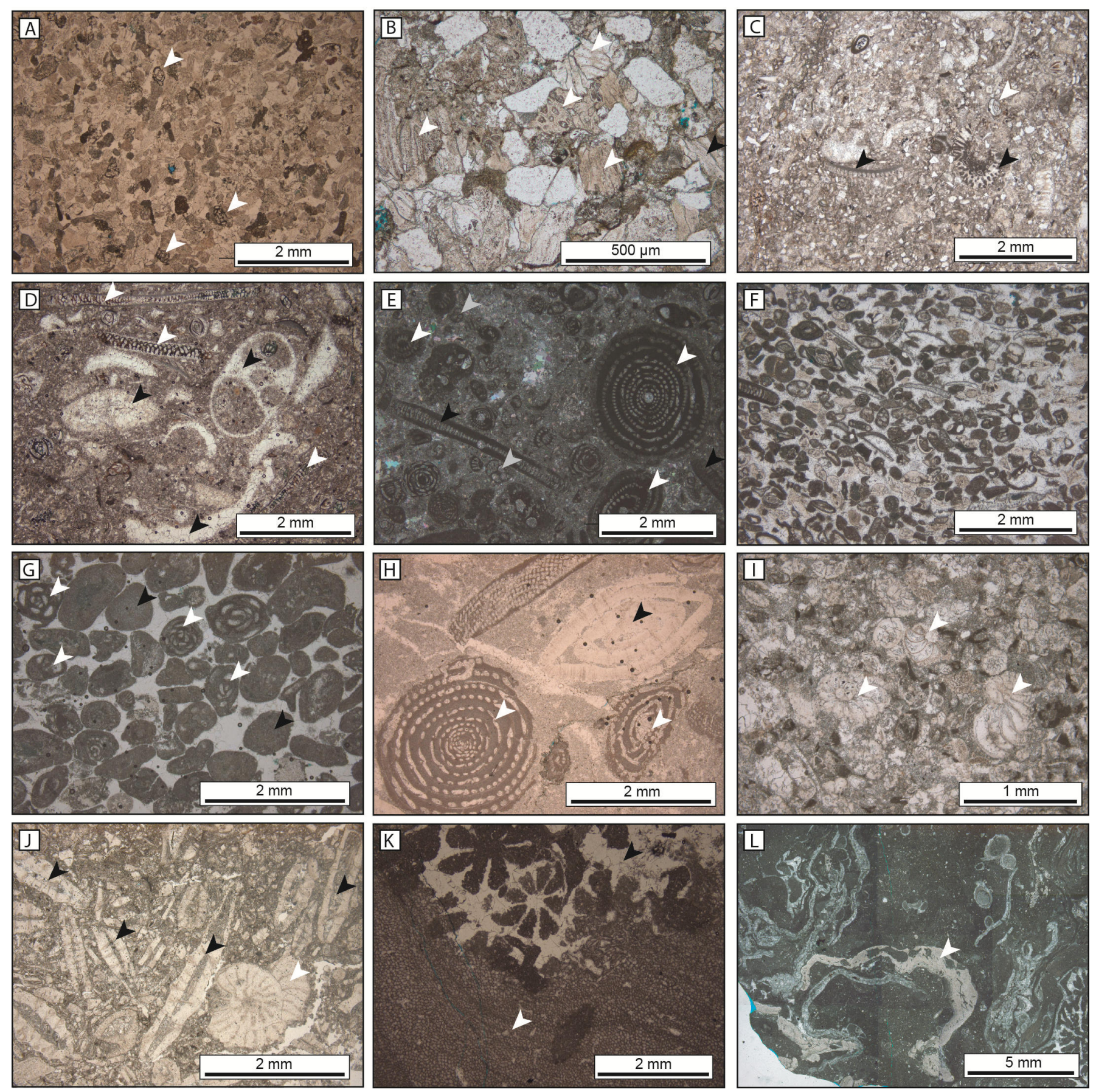

Figure 4 


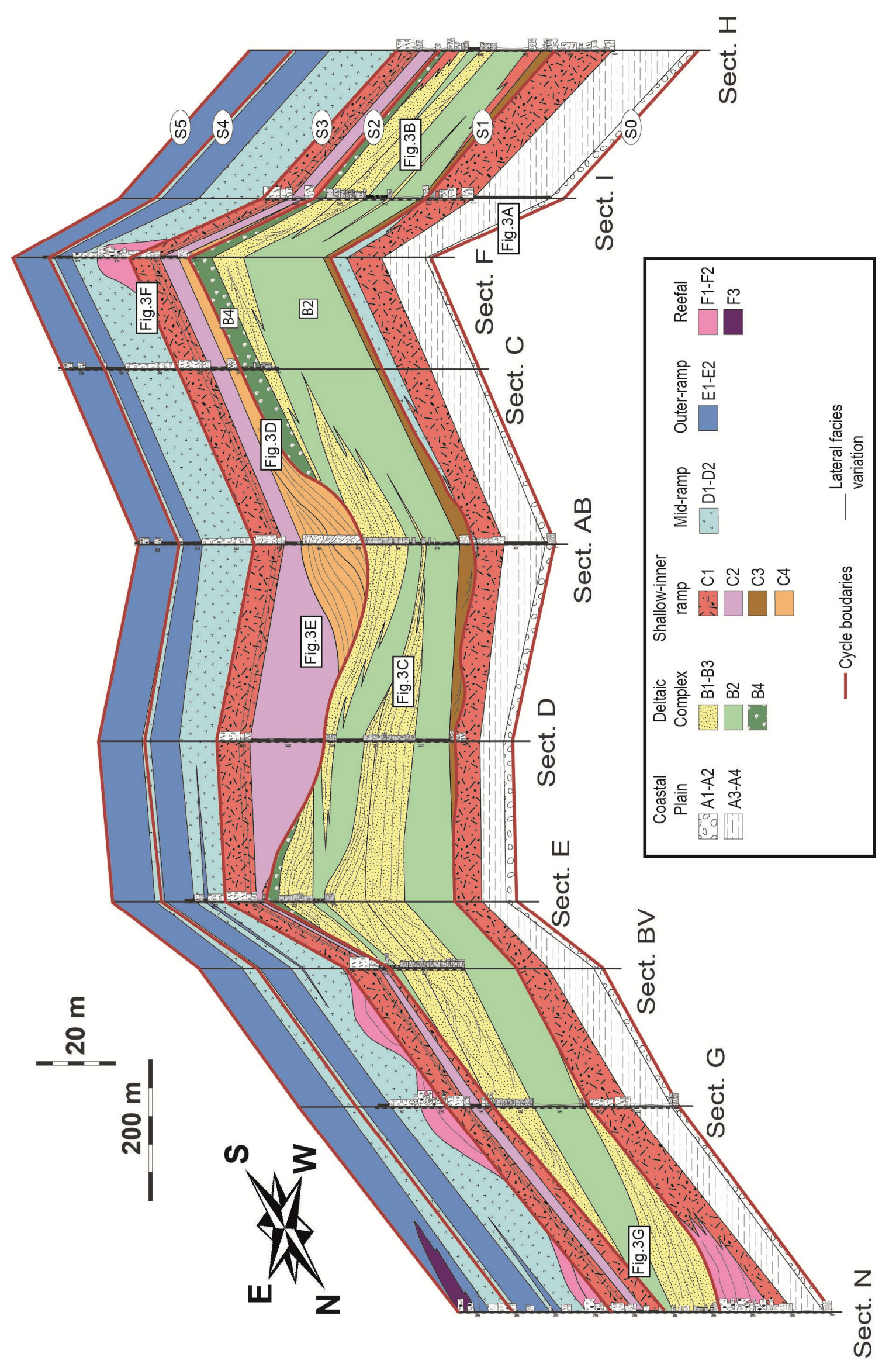

Figure 5 

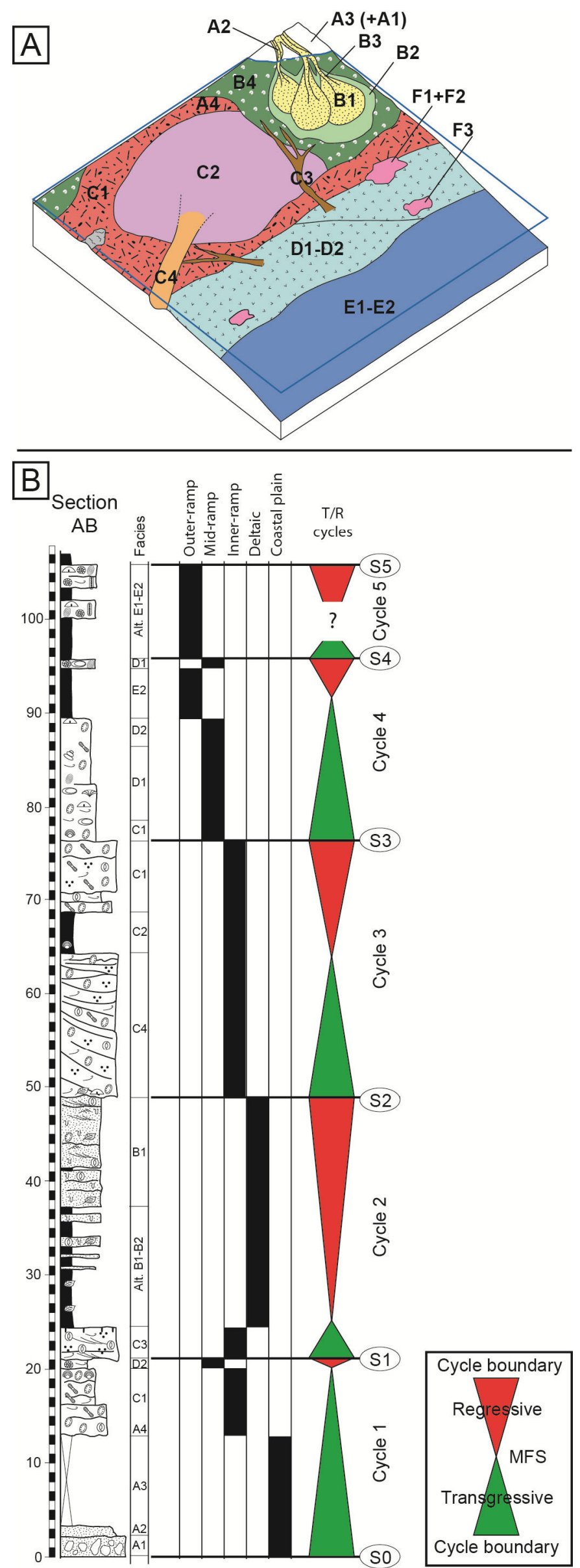

Figure 6 


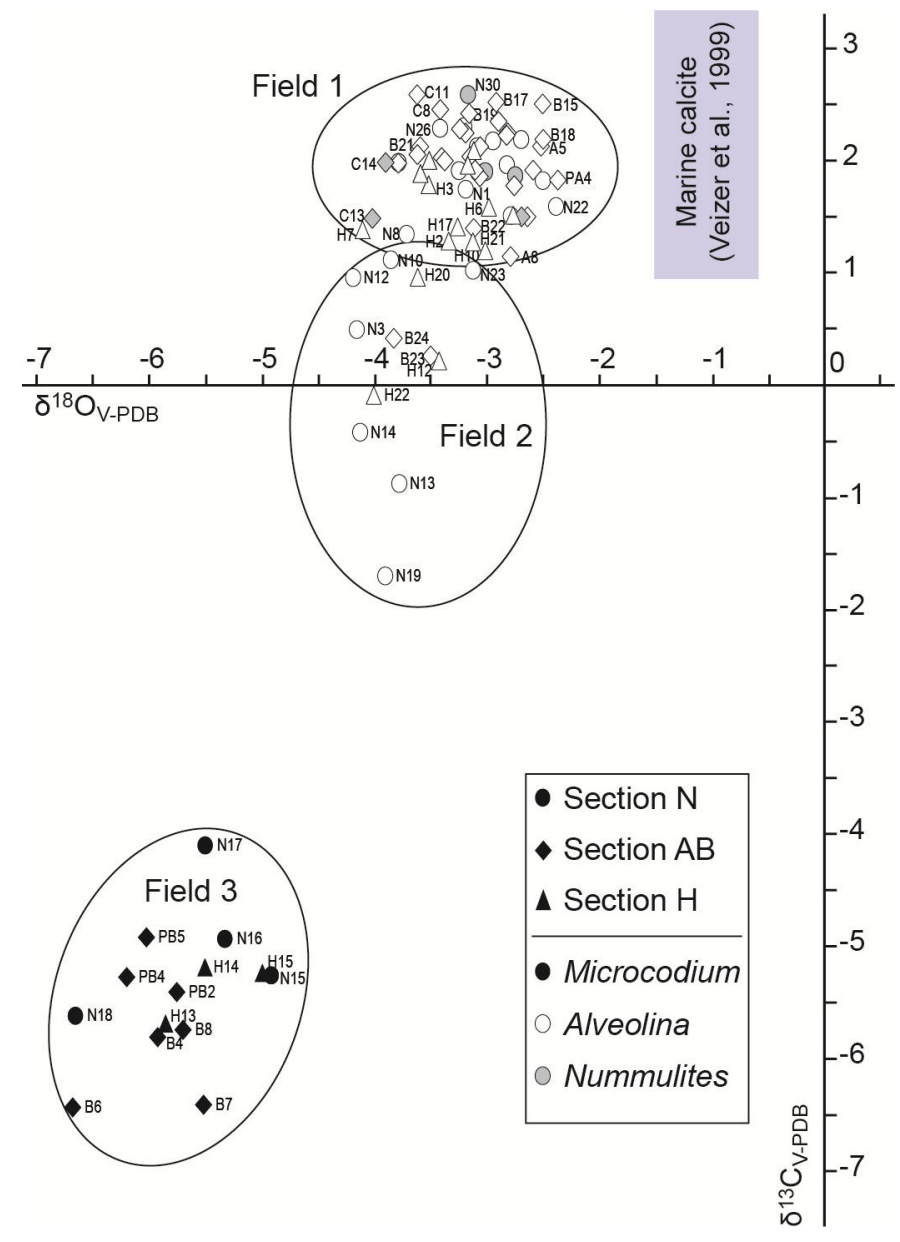

Figure 7 

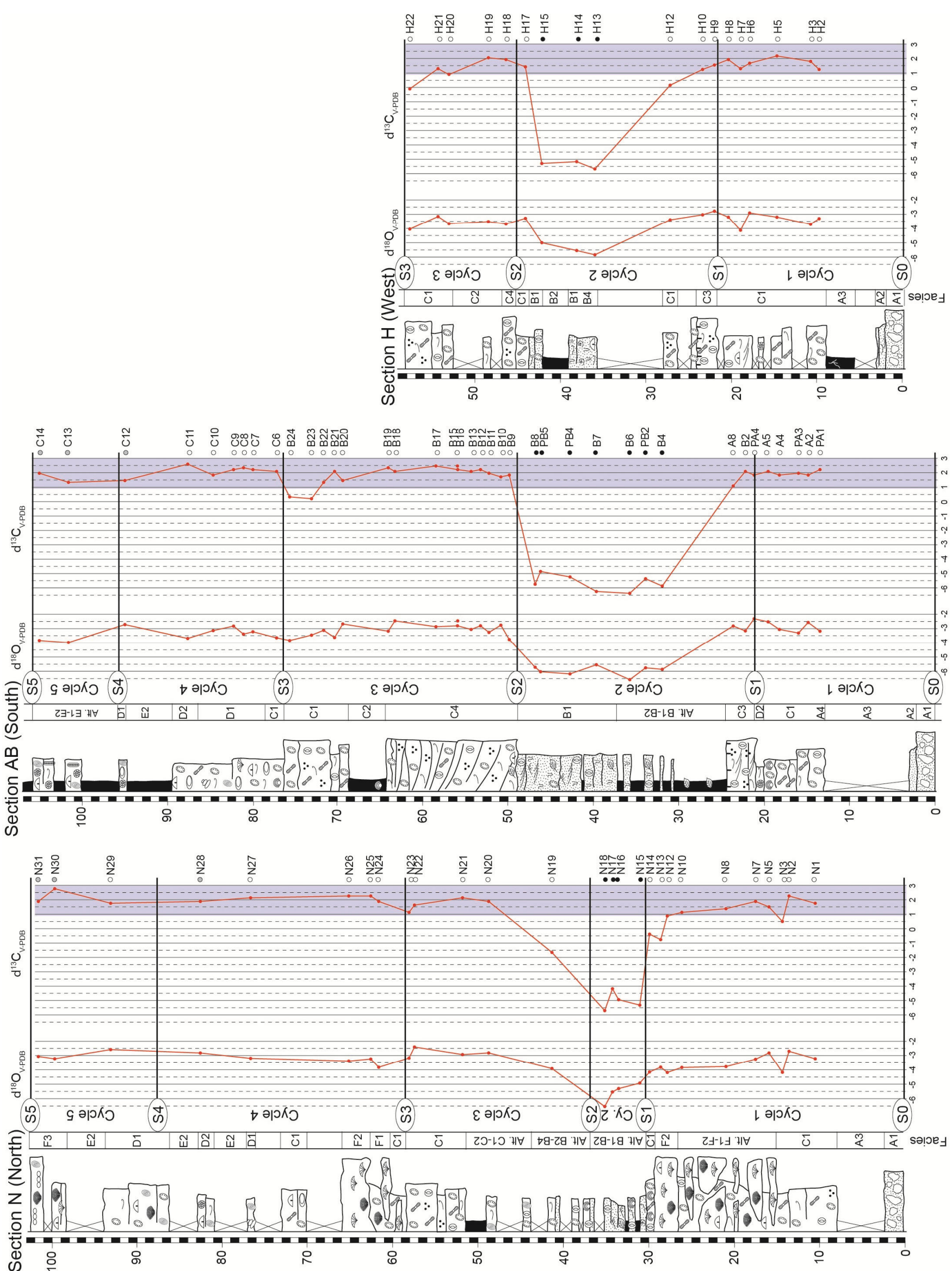

Figure 8 
A

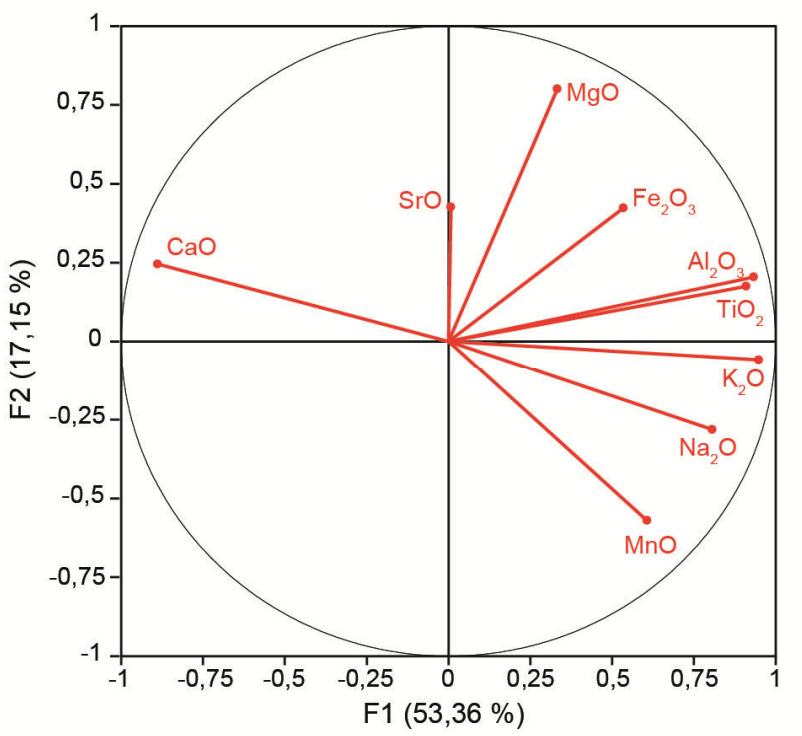

B

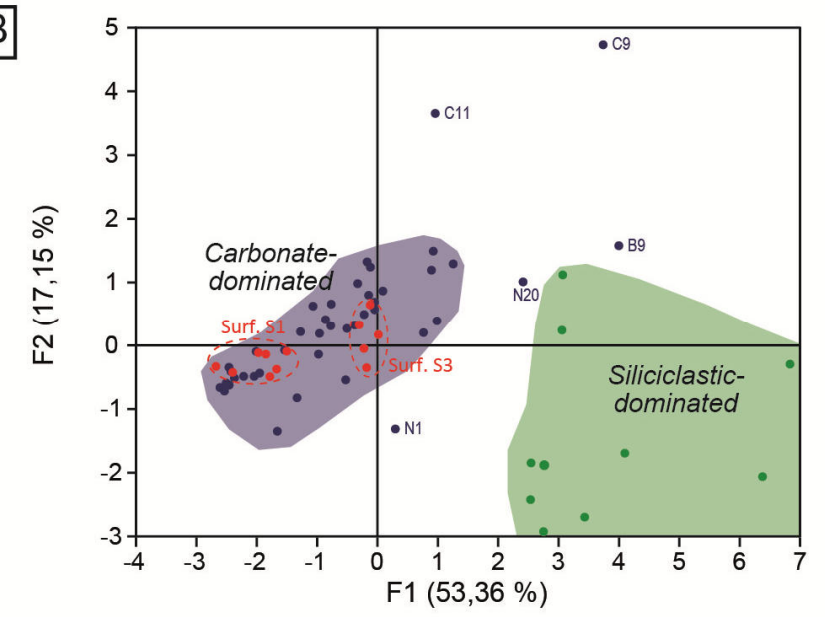

C

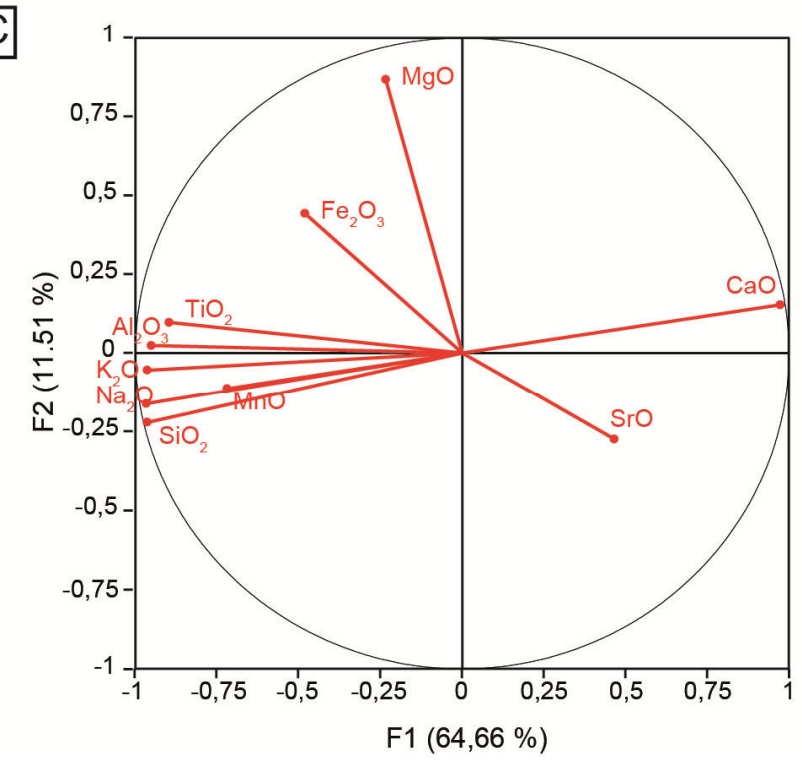

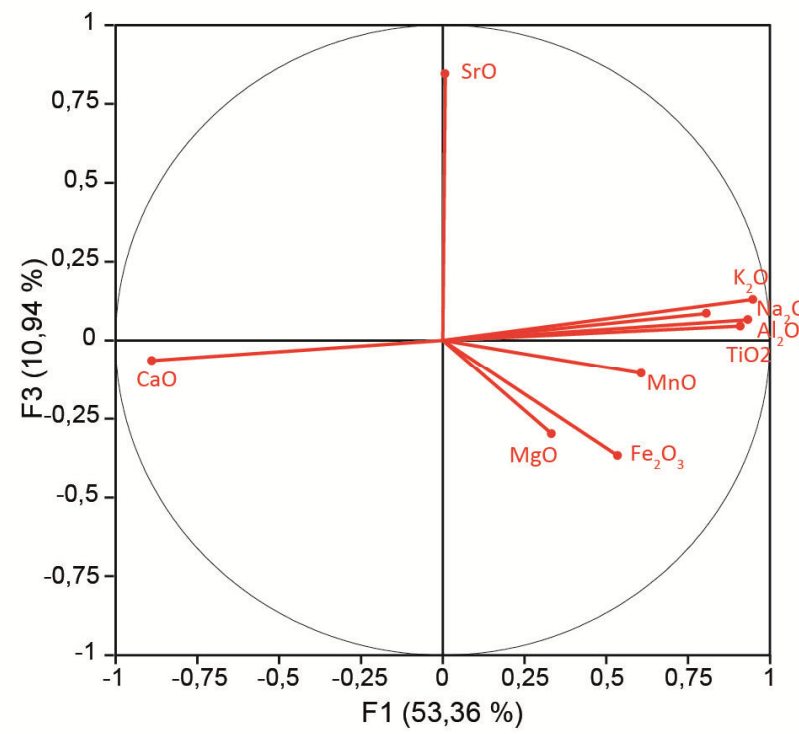
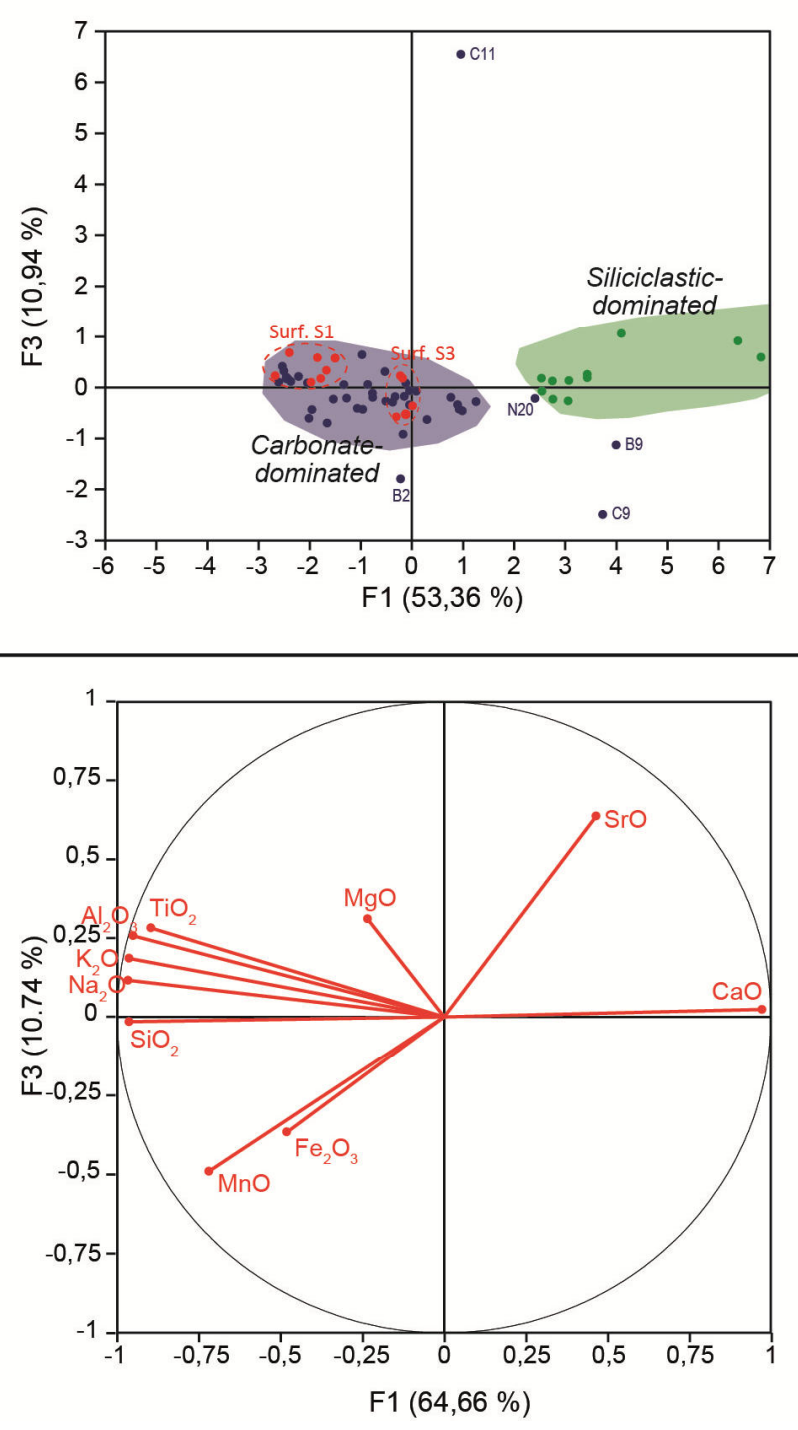

Figure 9 

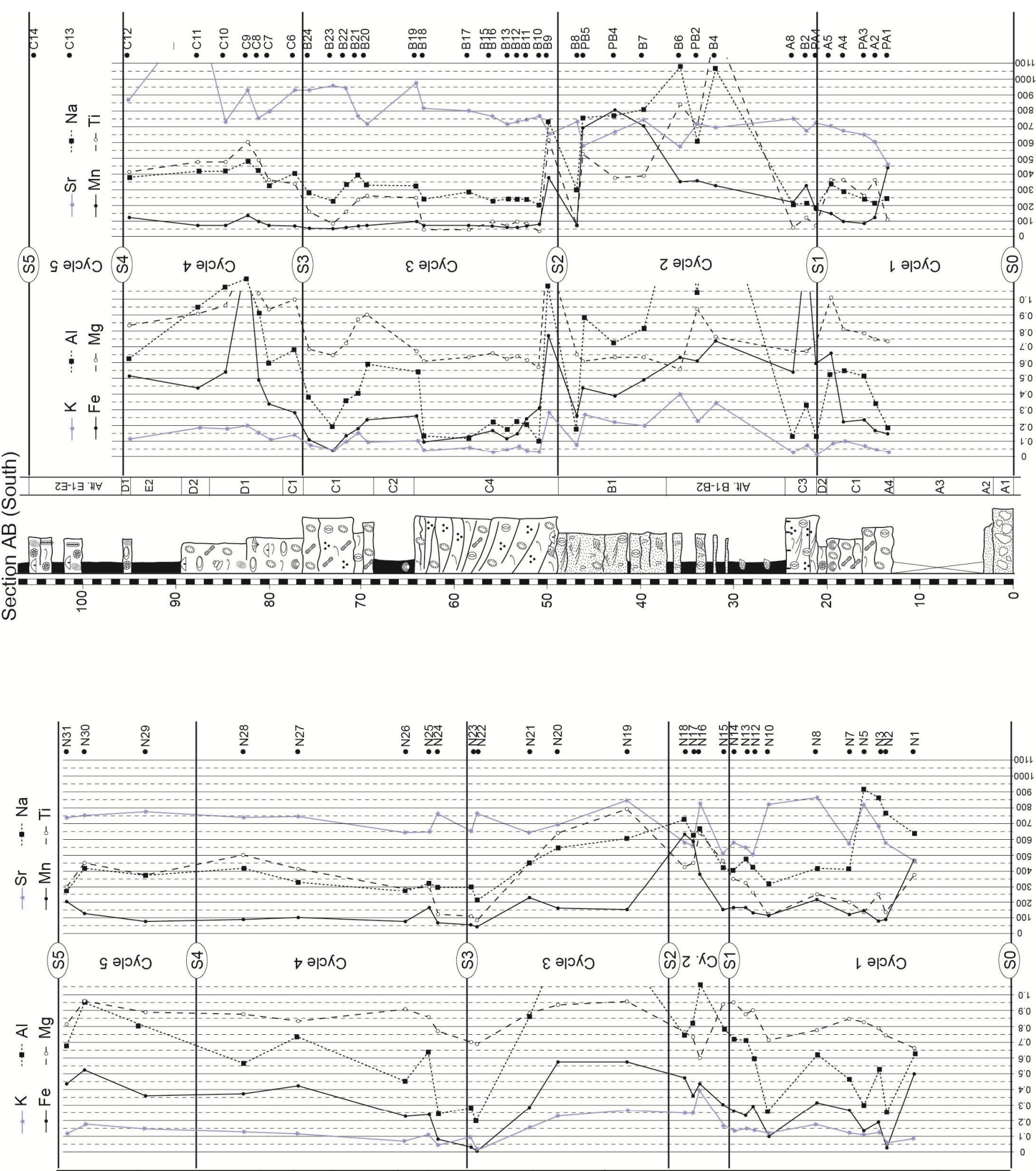

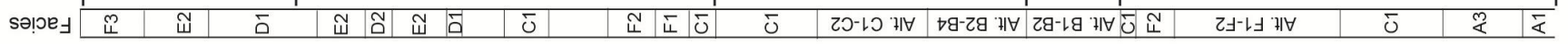

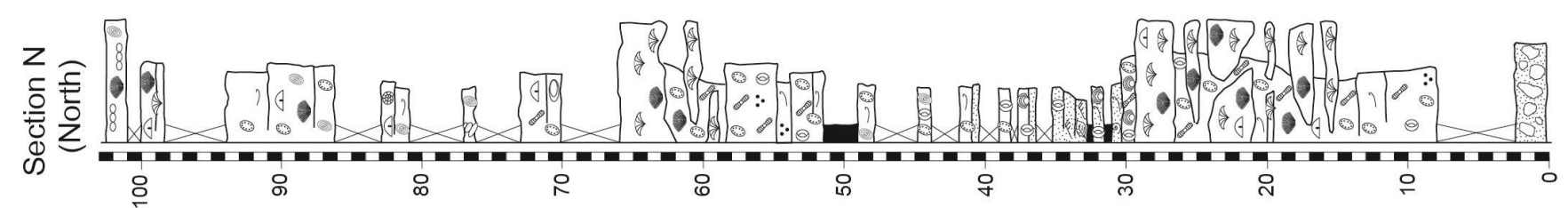

Figure 10 


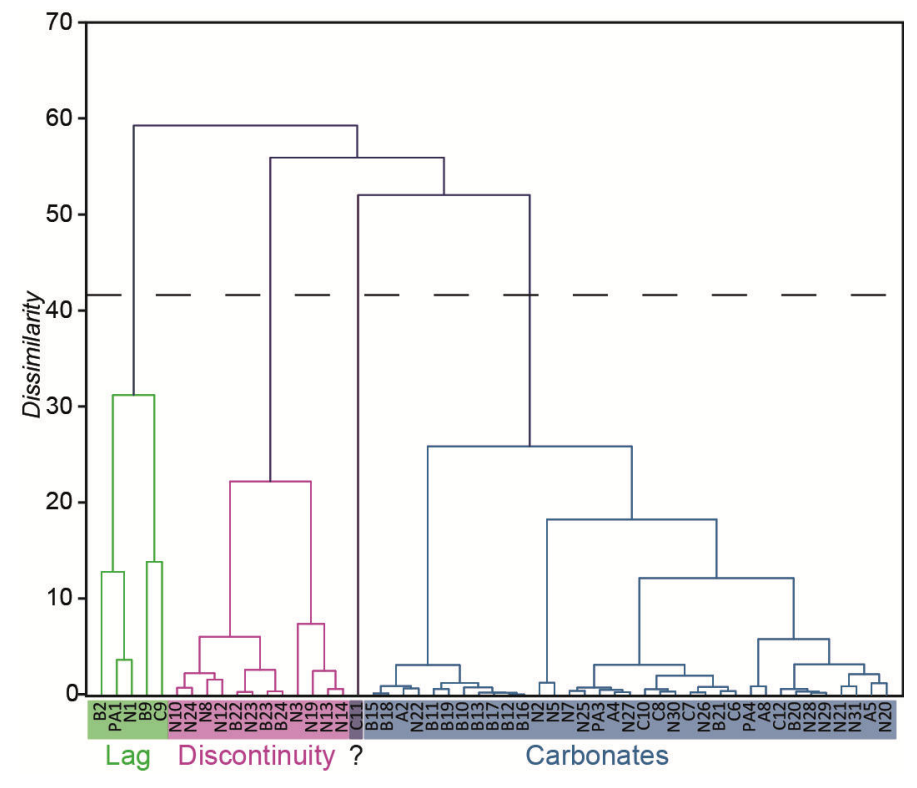

Figure 11 


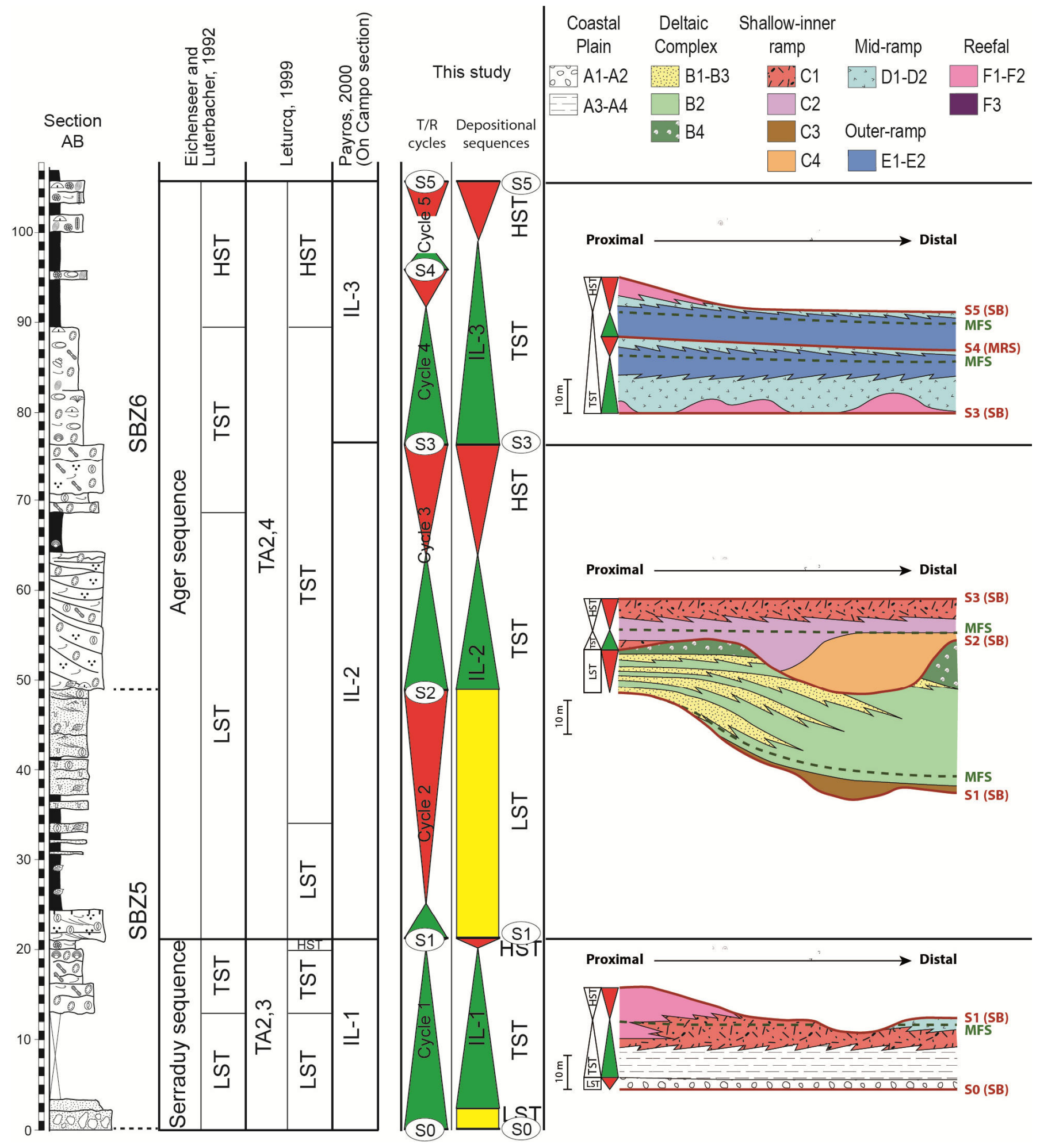

Figure 12 


\begin{tabular}{|c|c|c|c|c|c|c|c|c|c|c|c|c|c|c|c|c|}
\hline $\begin{array}{c}\text { Sample } \\
\text { name }\end{array}$ & $\begin{array}{c}\text { Section } \\
\text { name }\end{array}$ & Cycle & $\underset{\mathrm{m}}{\text { Height }}$ & $\begin{array}{c}\boldsymbol{\delta}^{13} \mathbf{C} \\
\% \text { V-PDB }\end{array}$ & $\begin{array}{c}\boldsymbol{\delta}^{18} \mathbf{O} \\
\% \text { V-PDB }\end{array}$ & $\begin{array}{c}\mathbf{F e}_{2} \mathbf{O}_{3} \\
\%\end{array}$ & $\underset{\%}{\mathbf{A l}_{2} \mathbf{O}_{3}}$ & $\underset{\%}{\mathrm{CaO}}$ & $\underset{\%}{\mathbf{M g O}}$ & $\underset{\%}{\mathrm{SiO}_{2}}$ & $\underset{\%}{\mathbf{K}_{2} \mathbf{O}}$ & $\begin{array}{c}\mathbf{M n O} \\
\mathrm{ppm}\end{array}$ & $\begin{array}{c}\mathrm{Na}_{2} \mathbf{O} \\
\text { ppm }\end{array}$ & $\begin{array}{l}\text { SrO } \\
\text { ppm }\end{array}$ & $\begin{array}{l}\mathbf{T i O}_{2} \\
\text { ppm }\end{array}$ & $\begin{array}{c}\mathbf{M g} / \mathbf{C a} \\
\text { Molar } \\
\text { ratio }\end{array}$ \\
\hline PA1 & $\mathrm{AB}$ & Cy. 1 & 13,5 & 2,24 & $-3,19$ & 0,143 & 0,187 & 53,85 & 0,729 & 1,16 & 0,03 & 439,50 & 243,99 & 458 & 113,59 & 2,185 \\
\hline A2 & $\mathrm{AB}$ & Су. 1 & 14,9 & 1,91 & $-2,58$ & 0,164 & 0,340 & 54,59 & 0,745 & 1,35 & 0,05 & 121,88 & 213,84 & 602 & 367,74 & 2,201 \\
\hline PA3 & $\mathrm{AB}$ & Су. 1 & 16 & 2,02 & $-3,40$ & 0,231 & 0,514 & 54,13 & 0,784 & 1,73 & 0,07 & 87,32 & 245,20 & 648 & 264,50 & 2,335 \\
\hline A4 & $\mathrm{AB}$ & Су. 1 & 18 & 1,85 & $-3,06$ & 0,223 & 0,548 & 53,91 & 0,810 & 1,95 & 0,10 & 95,71 & 289,61 & 673 & 367,74 & 2,420 \\
\hline A5 & $\mathrm{AB}$ & Су. 1 & 19,7 & 2,12 & $-2,51$ & 0,652 & 0,524 & 53,30 & 1,005 & 1,89 & 0,09 & 145,66 & 332,31 & 703 & 367,74 & 3,018 \\
\hline PA4 & $\mathrm{AB}$ & Су. 2 & 21,2 & 1,83 & $-2,37$ & 0,593 & 0,130 & 53,11 & 0,716 & 1,56 & 0,01 & 176,96 & 187,28 & 725 & 71,15 & 2,176 \\
\hline B2 & $\mathrm{AB}$ & Су. 2 & 22,1 & 2,04 & $-3,14$ & 1,738 & 0,327 & 52,06 & 0,673 & 1,97 & 0,07 & 322,99 & 215,42 & 676 & 120,10 & 2,088 \\
\hline A8 & $\mathrm{AB}$ & Су. 2 & 23,8 & 1,15 & $-2,79$ & 0,542 & 0,130 & 53,39 & 0,673 & 1,69 & 0,03 & 220,60 & 208,36 & 747 & 57,20 & 2,037 \\
\hline B4 & $\mathrm{AB}$ & Cу. 2 & 31,9 & $-5,78$ & $-5,92$ & 0,735 & 1,788 & 40,52 & 0,761 & 21,80 & 0,34 & 323,09 & 1052,9 & 694 & 1395,2 & 3,005 \\
\hline PB2 & $\mathrm{AB}$ & Су. 2 & 33,9 & $-5,39$ & $-5,75$ & 0,606 & 1,044 & 46,12 & 0,939 & 13,29 & 0,23 & 354,22 & 602,85 & 716 & 704,93 & 3,250 \\
\hline B6 & $\mathrm{AB}$ & Су. 2 & 35,8 & $-6,41$ & $-6,68$ & 0,631 & 1,691 & 34,32 & 0,554 & 32,90 & 0,40 & 347,67 & 1076,3 & 573 & 829,13 & 2,595 \\
\hline B7 & $\mathrm{AB}$ & Су. 2 & 39,8 & $-6,38$ & $-5,51$ & 0,492 & 0,814 & 46,72 & 0,629 & 13,20 & 0,20 & 704,26 & 799,82 & 743 & 382,85 & 2,173 \\
\hline PB4 & $\mathrm{AB}$ & Су. 2 & 42,8 & $-5,25$ & $-6,20$ & 0,386 & 0,724 & 44,48 & 0,637 & 16,51 & 0,22 & 799,48 & 767,99 & 665 & 370,01 & 2,309 \\
\hline PB5 & $\mathrm{AB}$ & Су. 2 & 46 & $\begin{array}{l}-4,90 \\
\end{array}$ & $\begin{array}{l}-6,02 \\
\end{array}$ & 0,438 & 0,882 & 42,59 & 0,607 & 21,34 & 0,27 & 689,93 & 753,25 & 578 & 528,84 & 2,298 \\
\hline B8 & $\mathrm{AB}$ & Су. 2 & 46,8 & $-5,72$ & $-5,70$ & 0,252 & 0,183 & 54,73 & 0,651 & 0,69 & 0,08 & 78,01 & 295,28 & 732 & 70,75 & 1,924 \\
\hline B9 & $\mathrm{AB}$ & Су. 3 & 50 & 1,97 & $-3,78$ & 0,765 & $\begin{array}{l}1,087 \\
\end{array}$ & 45,37 & 1,325 & $\begin{array}{l}12,99 \\
\end{array}$ & 0,28 & 375,61 & 731,15 & 653 & 613,87 & 4,599 \\
\hline B10 & $\mathrm{AB}$ & Cy. 3 & 50,9 & 1,78 & $-2,75$ & 0,309 & 0,101 & 54,57 & 0,569 & 0,36 & 0,03 & 78,31 & 194,78 & 764 & 36,05 & 1,691 \\
\hline B11 & $\mathrm{AB}$ & Су. 3 & 52,2 & 2,00 & $-3,37$ & 0,239 & 0,208 & 54,69 & 0,611 & 0,74 & 0,04 & 64,95 & 235,30 & 741 & 81,13 & 1,810 \\
\hline B12 & $\mathrm{AB}$ & Су. 3 & 53,2 & 2,24 & $-2,81$ & 0,143 & 0,225 & 54,85 & 0,640 & 0,89 & 0,07 & 59,83 & 238,04 & 733 & 99,01 & 1,888 \\
\hline B13 & $\mathrm{AB}$ & Су. 3 & 54,2 & 2,12 & $-3,05$ & 0,113 & 0,175 & 54,65 & 0,624 & 0,66 & 0,05 & 59,95 & 234,06 & 715 & 67,42 & 1,851 \\
\hline B15 & $\mathrm{AB}$ & Cy. 3 & 56,1 & 2,50 & $-2,50$ & 0,160 & 0,221 & 55,11 & 0,643 & 0,84 & 0,03 & 65,50 & 227,81 & 762 & 102,83 & 1,888 \\
\hline B16 & $\mathrm{AB}$ & Су. 3 & 56,1 & 2,22 & $-2,82$ & 0,158 & 0,243 & 55,30 & 0,652 & 0,86 & 0,02 & 65,14 & 222,32 & 775 & 92,73 & 1,909 \\
\hline B17 & $\mathrm{AB}$ & Су. 3 & 58,6 & 2,51 & \begin{tabular}{|l|}
$-2,91$ \\
\end{tabular} & 0,127 & 0,116 & 56,07 & 0,628 & 0,47 & 0,06 & 70,51 & 282,65 & 801 & 53,01 & 1,816 \\
\hline B18 & $\mathrm{AB}$ & Су. 3 & 63,4 & 2,19 & $-2,49$ & 0,093 & 0,135 & 54,45 & 0,605 & 0,51 & 0,04 & 73,56 & 241,34 & 821 & 56,99 & 1,802 \\
\hline B19 & $\mathrm{AB}$ & Су. 3 & 64 & 2,42 & $-3,15$ & 0,254 & 0,542 & 53,37 & 0,666 & 1,86 & 0,10 & 97,15 & 322,30 & 980 & 247,56 & 2,019 \\
\hline B20 & $\mathrm{AB}$ & Су. 3 & $\begin{array}{l}69,8 \\
\end{array}$ & 1,50 & $-2,64$ & 0,231 & 0,589 & 53,23 & 0,900 & 2,20 & 0,09 & 69,04 & 328,48 & 715 & 260,93 & 2,714 \\
\hline B21 & $\mathrm{AB}$ & Су. 3 & 70,7 & 2,12 & $-3,59$ & 0,177 & 0,407 & 55,14 & 0,869 & 1,20 & 0,15 & 68,90 & 391,69 & 766 & 238,86 & 2,535 \\
\hline B22 & $\mathrm{AB}$ & Cy. 3 & 72 & 1,40 & $-3,11$ & 0,136 & 0,356 & 53,71 & 0,718 & 1,04 & 0,10 & 55,60 & 320,89 & 943 & 161,25 & 2,159 \\
\hline B23 & $\mathrm{AB}$ & Су. 3 & 73,1 & 0,26 & $-3,49$ & 0,042 & 0,195 & 54,01 & 0,645 & 0,60 & 0,05 & 51,28 & 230,92 & 960 & 88,20 & 1,933 \\
\hline B24 & $\mathrm{AB}$ & Су. 3 & 75,6 & 0,42 & $-3,82$ & 0,107 & 0,381 & 54,99 & 0,683 & 1,21 & 0,07 & 54,41 & 277,34 & 933 & 158,10 & 2,007 \\
\hline C6 & $\mathrm{AB}$ & Су. 4 & 77,2 & 2,05 & $-3,61$ & 0,281 & 0,682 & 53,87 & 0,992 & nd & 0,14 & 65,01 & 398,92 & 932 & 338,12 & 2,949 \\
\hline C7 & $\mathrm{AB}$ & Сy. 4 & 80,1 & 2,28 & $-3,24$ & 0,336 & 0,600 & 52,70 & 0,937 & nd & 0,11 & 73,33 & 331,85 & 798 & 363,50 & 2,850 \\
\hline $\mathrm{C} 8$ & $\mathrm{AB}$ & Cy. 4 & 81,2 & 2,45 & $-3,41$ & 0,485 & 0,914 & 51,80 & 1,036 & nd & 0,15 & 94,95 & 419,66 & 753 & 489,70 & 3,195 \\
\hline C9 & $\mathrm{AB}$ & Су. 4 & 82,5 & 2,35 & $-2,89$ & 2,120 & 1,133 & 47,55 & 1,462 & nd & 0,20 & 131,20 & 479,41 & 932 & 608,23 & 4,830 \\
\hline C10 & $\mathrm{AB}$ & Cy. 4 & 84,9 & 1,91 & $-3,10$ & 0,531 & $\begin{array}{ll}1,079 \\
\end{array}$ & $\begin{array}{l}50,69 \\
\end{array}$ & 0,962 & nd & 0,18 & 75,70 & 411,77 & 734 & $\begin{array}{l}474,97 \\
\end{array}$ & 3,035 \\
\hline C11 & $\mathrm{AB}$ & Су. 4 & 87,8 & 2,58 & $-3,61$ & 0,437 & 0,955 & 51,59 & 0,904 & nd & 0,19 & 65,77 & 414,22 & 4567 & 476,16 & 2,810 \\
\hline C12 & $\mathrm{AB}$ & Сy. 4 & 95,2 & 1,50 & $-2,69$ & 0,508 & 0,624 & 53,32 & 0,836 & nd & 0,12 & 123,25 & 383,03 & 868 & 408,23 & 2,521 \\
\hline $\mathrm{C} 13$ & $\mathrm{AB}$ & Су. 5 & 101,3 & 1,49 & $-4,01$ & nd & nd & & nd & nd & nd & nd & nd & nd & nd & \\
\hline C14 & $\mathrm{AB}$ & Су. 5 & 105,2 & 1,98 & $-3,90$ & nd & nd & & nd & nd & nd & nd & nd & nd & nd & \\
\hline N1 & $\mathrm{N}$ & Cy. 1 & 10,6 & 1,75 & $-3,19$ & 0,498 & 0,629 & 56,00 & 0,662 & nd & 0,09 & 463,51 & 56,00 & 462 & 371,86 & 1,913 \\
\hline N2 & $\mathrm{N}$ & Су. 1 & 13,5 & 2,19 & $-2,69$ & 0,028 & 0,257 & 56,00 & 0,745 & nd & 0,06 & 86,30 & 56,00 & 577 & 135,37 & 2,147 \\
\hline
\end{tabular}




\begin{tabular}{|c|c|c|c|c|c|c|c|c|c|c|c|c|c|c|c|c|}
\hline N3 & $\mathrm{N}$ & Су. 1 & 14,2 & 0,50 & $-4,15$ & 0,197 & 0,527 & 56,00 & 0,788 & nd & 0,12 & 78,72 & 56,00 & 679 & 244,97 & 2,270 \\
\hline N5 & $\mathrm{N}$ & Су. 1 & 15,9 & 1,51 & $-2,79$ & 0,136 & 0,299 & 56,00 & 0,829 & nd & 0,11 & 142,78 & 56,00 & 818 & $\begin{array}{l}130,97 \\
\end{array}$ & 2,384 \\
\hline N7 & $\mathrm{N}$ & Cy. 1 & 17,3 & 1,91 & $-3,25$ & 0,271 & 0,466 & 56,00 & 0,849 & nd & 0,12 & 119,63 & 56,00 & 572 & 192,09 & 2,440 \\
\hline N8 & $\mathrm{N}$ & Су. 1 & 21,1 & 1,35 & $-3,71$ & 0,313 & 0,620 & 55,30 & 0,777 & nd & 0,17 & 217,35 & 55,30 & 864 & 254,33 & 2,267 \\
\hline N10 & $\mathrm{N}$ & Cy. 1 & 26 & 1,12 & $-3,85$ & 0,103 & 0,259 & 55,09 & 0,717 & nd & 0,12 & 112,68 & 55,09 & 815 & 118,49 & 2,103 \\
\hline N12 & $\mathrm{N}$ & Су. 1 & 27,7 & 0,96 & $-4,19$ & 0,290 & 0,595 & 53,73 & 0,902 & nd & 0,14 & 129,02 & 53,73 & 500 & 261,59 & 2,697 \\
\hline N13 & $\mathrm{N}$ & Cy. 1 & 28,5 & $-0,87$ & $\begin{array}{l}3,78 \\
\end{array}$ & 0,235 & 0,708 & 54,12 & 0,881 & nd & 0,15 & 164,12 & 54,12 & 546 & 316,28 & 2,616 \\
\hline N14 & $\mathrm{N}$ & Cy. 1 & 29,8 & $-0,41$ & $\begin{array}{l}-4,12 \\
\end{array}$ & 0,262 & 0,719 & 55,20 & 0,953 & nd & 0,13 & 162,64 & 55,20 & 574 & 342,22 & 2,769 \\
\hline N15 & $\mathrm{N}$ & Cy. 2 & 30,9 & $-5,24$ & $-4,91$ & 0,299 & 0,781 & 48,00 & 0,943 & nd & 0,16 & 149,78 & 48,00 & 513 & 467,96 & 3,141 \\
\hline N16 & $\mathrm{N}$ & Cy. 2 & 33,5 & $-4,91$ & $-5,33$ & 0,440 & 1,063 & 39,45 & 0,603 & nd & 0,39 & 376,82 & 39,45 & 825 & 643,04 & 2,459 \\
\hline N17 & $\mathrm{N}$ & Cy. 2 & 34,2 & $-4,08$ & $-5,50$ & 0,355 & 0,816 & 45,03 & 0,735 & nd & 0,25 & 587,53 & 45,03 & 559 & 445,22 & 2,622 \\
\hline N18 & $\mathrm{N}$ & Су. 2 & 35,1 & $-5,59$ & $-6,65$ & 0,468 & 0,748 & 45,43 & 0,762 & nd & 0,25 & 636,61 & 45,43 & 574 & 420,60 & 2,694 \\
\hline N19 & $\mathrm{N}$ & Cу. 3 & 41,5 & $-1,69$ & $-3,90$ & 0,577 & 1,245 & 48,50 & 0,957 & nd & 0,26 & 150,72 & 48,50 & 839 & 789,19 & 3,154 \\
\hline $\mathrm{N} 20$ & $\mathrm{~N}$ & Cy. 3 & 48,8 & 1,96 & $-2,82$ & 0,576 & 1,280 & 50,19 & 0,939 & nd & 0,23 & 157,80 & 50,19 & 690 & 643,32 & 2,993 \\
\hline $\mathrm{N} 21$ & $\mathrm{~N}$ & Cу. 3 & 51,9 & 2,18 & $-2,94$ & 0,283 & 0,863 & 51,83 & 0,883 & nd & 0,16 & 223,04 & 51,83 & 642 & 446,14 & 2,734 \\
\hline N22 & $\mathrm{N}$ & Cy. 3 & 57,1 & 1,59 & $-2,38$ & $-0,001$ & 0,201 & 55,08 & 0,692 & nd & 0,02 & 44,34 & 55,08 & 756 & $\begin{array}{l}78,45 \\
\end{array}$ & 2,032 \\
\hline $\mathrm{N} 23$ & $\mathrm{~N}$ & Cy. 3 & 57,3 & 1,02 & $-3,12$ & 0,038 & 0,284 & 53,29 & 0,705 & nd & 0,09 & 52,86 & 53,29 & 653 & 112,61 & 2,137 \\
\hline $\mathrm{N} 24$ & $\mathrm{~N}$ & Су. 4 & 61,6 & 1,99 & $-3,78$ & 0,079 & 0,245 & 53,86 & 0,772 & nd & 0,05 & 67,66 & 53,86 & 759 & 121,75 & 2,311 \\
\hline $\mathrm{N} 25$ & $\mathrm{~N}$ & Cy. 4 & 63,5 & 2,30 & $-3,20$ & 0,240 & 0,638 & 53,48 & 0,858 & nd & 0,11 & 163,50 & 53,48 & 650 & 296,25 & 2,580 \\
\hline N26 & $\mathrm{N}$ & Су. 4 & 65 & 2,29 & $\begin{array}{l}-3,41 \\
\end{array}$ & 0,227 & 0,453 & 52,95 & 0,906 & nd & 0,07 & 75,31 & 52,95 & 641 & 288,90 & 2,747 \\
\hline $\mathrm{N} 27$ & $\mathrm{~N}$ & Су. 4 & 76,6 & 2,12 & $-3,09$ & 0,425 & 0,731 & 52,58 & 0,832 & nd & 0,12 & 96,85 & 52,58 & 634 & 416,22 & 2,545 \\
\hline $\mathrm{N} 28$ & $\mathrm{~N}$ & Cy. 4 & 82,5 & 1,87 & $-2,75$ & 0,366 & 0,566 & 55,11 & 0,878 & nd & 0,13 & 82,08 & 55,11 & 739 & 499,70 & 2,561 \\
\hline N29 & $\mathrm{N}$ & Cy. 5 & 92,9 & 1,82 & $-2,50$ & 0,360 & 0,803 & 53,30 & 0,891 & nd & 0,15 & 77,94 & 53,30 & 773 & 371,63 & 2,686 \\
\hline N30 & $\mathrm{N}$ & Cy. 5 & 99,8 & 2,59 & $-3,17$ & 0,528 & 0,951 & 53,05 & 0,958 & nd & 0,18 & 124,94 & 53,05 & 753 & 449,61 & 2,895 \\
\hline N31 & $\mathrm{N}$ & Cy. 5 & 101,8 & 1,90 & $-3,01$ & 0,439 & 0,677 & 54,02 & 0,812 & nd & 0,12 & 204,72 & 54,02 & 735 & 296,12 & 2,419 \\
\hline $\mathrm{H} 2$ & $\mathrm{H}$ & Cy. 1 & 10 & 1,28 & $-3,34$ & nd & nd & nd & nd & nd & nd & nd & nd & nd & nd & nd \\
\hline H3 & $\mathrm{H}$ & Cy. 1 & 11 & 1,79 & \begin{tabular}{|c|}
$-3,51$ \\
\end{tabular} & nd & nd & nd & nd & nd & nd & nd & nd & nd & nd & nd \\
\hline H5 & $\mathrm{H}$ & Cy. 1 & 15,1 & 2,09 & $-3,11$ & nd & nd & nd & nd & nd & nd & nd & nd & nd & nd & nd \\
\hline H6 & $\mathrm{H}$ & Cy. 1 & 18,3 & 1,58 & $-2,98$ & nd & nd & nd & nd & nd & nd & nd & nd & nd & nd & nd \\
\hline H7 & $\mathrm{H}$ & Су. 1 & 19,2 & 1,38 & $-4,10$ & nd & nd & nd & nd & nd & nd & nd & nd & nd & nd & nd \\
\hline H8 & $\mathrm{H}$ & Су. 1 & 20,7 & 1,96 & $-3,17$ & nd & nd & nd & nd & nd & nd & nd & nd & nd & nd & nd \\
\hline H9 & $\mathrm{H}$ & Су. 2 & 22,2 & 1,51 & $-2,76$ & nd & nd & nd & nd & nd & nd & nd & nd & nd & nd & nd \\
\hline H10 & $\mathrm{H}$ & Су. 2 & 23,8 & 1,20 & $-3,01$ & nd & nd & nd & nd & nd & nd & nd & nd & nd & nd & nd \\
\hline H12 & $\mathrm{H}$ & Cy. 2 & 27,5 & 0,22 & $\begin{array}{l}-3,42 \\
\end{array}$ & nd & nd & nd & nd & nd & nd & nd & nd & nd & nd & nd \\
\hline H13 & $\mathrm{H}$ & Cy. 2 & 36,1 & $-5,67$ & $-5,85$ & nd & nd & nd & nd & nd & nd & nd & nd & nd & nd & nd \\
\hline H14 & $\mathrm{H}$ & Су. 2 & 38,4 & $-5,16$ & $-5,50$ & nd & nd & nd & nd & nd & nd & nd & nd & nd & nd & nd \\
\hline H15 & $\mathrm{H}$ & Cy. 2 & 42,5 & $-5,21$ & $\begin{array}{l}-4,99 \\
\end{array}$ & nd & nd & nd & nd & nd & nd & nd & nd & nd & nd & nd \\
\hline H17 & $\mathrm{H}$ & Cy. 2 & 44,3 & 1,41 & $-3,25$ & nd & nd & nd & nd & nd & nd & nd & nd & nd & nd & nd \\
\hline H18 & $\mathrm{H}$ & Cy. 3 & 46,7 & 1,88 & $-3,59$ & nd & nd & nd & nd & nd & nd & nd & nd & nd & nd & nd \\
\hline H19 & $\mathrm{H}$ & Cy. 3 & 48,9 & 2,00 & $-3,51$ & nd & nd & nd & nd & nd & nd & nd & nd & nd & nd & nd \\
\hline $\mathrm{H} 20$ & $\mathrm{H}$ & Су. 3 & 53,4 & $\begin{array}{l}0,97 \\
\end{array}$ & $\begin{array}{l}-3,61 \\
\end{array}$ & nd & nd & nd & nd & nd & nd & nd & nd & nd & nd & nd \\
\hline $\mathrm{H} 21$ & $\mathrm{H}$ & Cy. 3 & 54,8 & 1,28 & $-3,12$ & nd & nd & nd & nd & nd & nd & nd & nd & nd & nd & nd \\
\hline $\mathrm{H} 22$ & $\mathrm{H}$ & Cy. 3 & 57,9 & $-0,09$ & $\begin{array}{l}-4,00 \\
\end{array}$ & nd & nd & nd & nd & nd & nd & nd & nd & nd & nd & nd \\
\hline
\end{tabular}


Table 2A

\begin{tabular}{|c|c|c|c|c|c|c|c|c|c|}
\hline Variables & $\mathrm{MgO}$ & $\mathrm{SrO}$ & $\mathrm{Fe}_{2} \mathrm{O}_{3}$ & $\mathrm{MnO}$ & $\mathrm{Al}_{2} \mathrm{O}_{3}$ & $\mathrm{TiO}_{2}$ & $\mathrm{Na}_{2} \mathrm{O}$ & $\mathrm{CaO}$ & $\mathrm{K}_{2} \mathrm{O}$ \\
\hline $\mathrm{MgO}$ & 1 & 0,084 & 0,470 & $-0,161$ & 0,436 & 0,397 & 0,092 & $-0,038$ & 0,247 \\
\hline $\mathrm{SrO}$ & 0,084 & 1 & 0,036 & $-0,178$ & 0,085 & 0,045 & $-0,067$ & 0,029 & 0,052 \\
\hline $\mathrm{Fe}_{2} \mathrm{O}_{3}$ & 0,470 & 0,036 & 1 & 0,267 & 0,466 & 0,436 & 0,206 & $-0,412$ & 0,369 \\
\hline $\mathrm{MnO}$ & $-0,161$ & $-0,178$ & 0,267 & 1 & 0,364 & 0,355 & 0,580 & $-0,652$ & 0,538 \\
\hline $\mathrm{Al}_{2} \mathrm{O}_{3}$ & 0,436 & 0,085 & 0,466 & 0,364 & 1 & 0,947 & 0,680 & $-0,759$ & 0,894 \\
\hline $\mathrm{TiO}_{2}$ & 0,397 & 0,045 & 0,436 & 0,355 & 0,947 & 1 & 0,663 & $-0,744$ & 0,843 \\
\hline $\mathrm{Na}_{2} \mathrm{O}$ & 0,092 & $-0,067$ & 0,206 & 0,580 & 0,680 & 0,663 & 1 & $-0,673$ & 0,777 \\
\hline $\mathrm{CaO}$ & $-0,038$ & 0,029 & $-0,412$ & $-0,652$ & $-0,759$ & $-0,744$ & $-0,673$ & 1 & $-0,869$ \\
\hline $\mathrm{K}_{2} \mathrm{O}$ & 0,247 & 0,052 & 0,369 & 0,538 & 0,894 & 0,843 & 0,777 & $-0,869$ & 1 \\
\hline
\end{tabular}

Table 2B

\begin{tabular}{|c|c|c|c|c|c|c|c|c|c|c|}
\hline Variables & $\mathrm{MgO}$ & $\mathrm{SrO}$ & $\mathrm{Fe}_{2} \mathrm{O}_{3}$ & $\mathrm{MnO}$ & $\mathrm{Al}_{2} \mathrm{O}_{3}$ & $\mathrm{TiO}_{2}$ & $\mathrm{Na}_{2} \mathrm{O}$ & $\mathrm{CaO}$ & $\mathrm{K}_{2} \mathrm{O}$ & $\mathrm{SiO}_{2}$ \\
\hline $\mathrm{MgO}$ & 1 & $-0,169$ & 0,239 & 0,022 & 0,291 & 0,331 & 0,146 & $-0,085$ & 0,249 & 0,033 \\
\hline $\mathrm{SrO}$ & $-0,169$ & 1 & $-0,303$ & $-0,498$ & $-0,316$ & $-0,332$ & $-0,319$ & 0,408 & $-0,312$ & $-0,412$ \\
\hline $\mathrm{Fe}_{2} \mathrm{O}_{3}$ & 0,239 & $-0,303$ & 1 & 0,408 & 0,386 & 0,359 & 0,327 & $-0,441$ & 0,367 & 0,364 \\
\hline $\mathrm{MnO}$ & 0,022 & $-0,498$ & 0,408 & 1 & 0,508 & 0,443 & 0,694 & $-0,706$ & 0,610 & 0,698 \\
\hline $\mathrm{Al}_{2} \mathrm{O}_{3}$ & 0,291 & $-0,316$ & 0,386 & 0,508 & 1 & 0,957 & 0,931 & $-0,912$ & 0,951 & 0,903 \\
\hline $\mathrm{TiO}_{2}$ & 0,331 & $-0,332$ & 0,359 & 0,443 & 0,957 & 1 & 0,862 & $-0,826$ & 0,875 & 0,816 \\
\hline $\mathrm{Na}_{2} \mathrm{O}$ & 0,146 & $-0,319$ & 0,327 & 0,694 & 0,931 & 0,862 & 1 & $-0,952$ & 0,970 & 0,958 \\
\hline $\mathrm{CaO}$ & $-0,085$ & 0,408 & $-0,441$ & $-0,706$ & $-0,912$ & $-0,826$ & $-0,952$ & 1 & $-0,941$ & $-0,991$ \\
\hline$K_{2} \mathrm{O}$ & 0,249 & $-0,312$ & 0,367 & 0,610 & 0,951 & 0,875 & 0,970 & $-0,941$ & 1 & 0,943 \\
\hline $\mathrm{SiO}_{2}$ & 0,033 & $-0,412$ & 0,364 & 0,698 & 0,903 & 0,816 & 0,958 & $-0,991$ & 0,943 & 1 \\
\hline
\end{tabular}

5 Table 2 